\title{
Miocene tectonics of the Maramures area (Northern Romania): implications for the Mid-Hungarian fault zone
}

\author{
M. Tischler · H. R. Gröger · B. Fügenschuh • \\ S. M. Schmid
}

Received: 20 May 2005/ Accepted: 10 June 2006/Published online: 11 August 2006

(C) Springer-Verlag 2006

\begin{abstract}
The interplay between the emplacement of crustal blocks (e.g. "ALCAPA", "Tisza", "Dacia") and subduction retreat is a key issue for understanding the Miocene tectonic history of the Carpathians. Coeval thrusting and basin formation is linked by transfer zones, such as the Mid-Hungarian fault zone, which seperates ALCAPA from Tisza-Dacia. The presented study provides new kinematic data from this transfer zone. Early Burdigalian (20.5 to $18.5 \mathrm{Ma}$ ) SE-directed thrusting of the easternmost tip of ALCAPA (Pienides), over Tisza-Dacia is linked to movements along the Mid-Hungarian fault zone and the Periadriatic line, accommodating the lateral extrusion of ALCAPA. Minor Late Burdigalian ( 18.5 to $16 \mathrm{Ma}) \mathrm{NE}-\mathrm{SW}$ extension is interpreted as related to back-arc extension. Post Burdigalian (post-16 Ma) NE-SW shortening and NW-SE extension correlate with "soft collision" of Tisza-Dacia with the European foreland coupled with southward migration of active subduction. During this stage the Bogdan-Voda and Dragos-Voda faults were kinematically linked to the Mid-Hungarian fault zone. Sinistral transpression (16 to $12 \mathrm{Ma}$ ) at the Bogdan-Voda fault was followed by sinistral transtension (12-10 Ma) along the coupled
\end{abstract}

M. Tischler $(\bowtie) \cdot$ H. R. Gröger $\cdot$ S. M. Schmid

Geologisch-Paläontologisches Institut, Basel University,

Bernoullistr. 32, 4056, Basel, Switzerland

e-mail: M.Tischler@unibas.ch

\section{B. Fügenschuh}

Institute for Geology and Paleontology,

Innsbruck University, Innrain 52f,

6020, Innsbruck, Austria
Bogdan-Dragos-Voda fault system. During the transtensional stage left-lateral offset was reduced eastwards by SW trending normal faults, the fault system finally terminating in an extensional horse-tail splay.

Keywords Kinematic analysis - Eastern Carpathians · Mid-Hungarian fault zone $\cdot$ Pienides $\cdot$ Miocene tectonics

\section{Introduction}

Miocene tectonics in the Carpathian region is characterised by the formation of an arcuate fold-and-thrustbelt and contemporaneous back arc extension in the Pannonian basin (e.g. Royden 1988). The European margin features a large-scale bight between the Moesian and Bohemian promontories (Fig. 1). According to most authors (e.g. Balla 1982; Mason et al. 1998) this Carpathian "embayment" was at least partly floored by oceanic crust. Slab retreat (e.g. Royden 1988; Wortel and Spakman 2000; Sperner et al. 2005) created the necessary space that allowed for the invasion of large continental blocks (ALCAPA, Tisza and Dacia; Balla 1987) and smaller displaced terranes (Fig. 1).

Invasion of the ALCAPA block lasted from the Late Oligocene to the Middle Miocene (Fodor et al. 1999), but initiated earlier in case of the Tisza and Dacia blocks (Fügenschuh and Schmid 2005). Emplacement was accompanied by substantial strikeslip movements, together with extension, shortening and rotations of rigid blocks (Ratschbacher et al. 1993; Fodor et al. 1999; Márton 2000; Márton and Fodor 2003; Csontos and Vörös 2004; Horváth et al. 2005). The major displaced units are, from NW to SE (Fig. 1): 


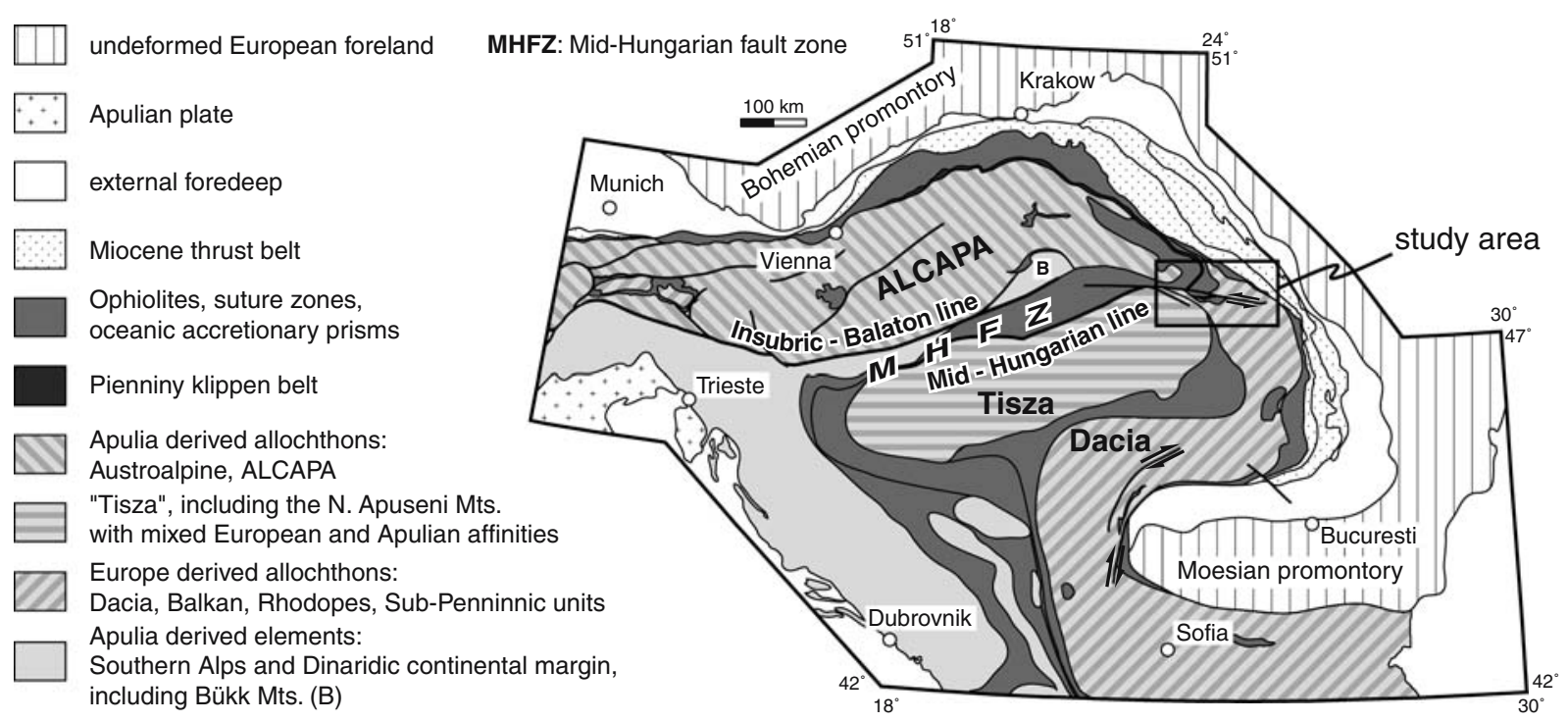

Fig. 1 Major tectonic units of the Alps, Carpathians, and Dinarides, simplified after an unpublished compilation by S. Schmid, B. Fügenschuh K. Ustaszewski, L. Matenco, R. Schuster and M. Tischler

1. Apulia-derived allochthons, such as the Austroalpine nappes of the Eastern Alps, that extend into the Central and Inner West-Carpathians (ALCAPA, e.g. Plasienka et al. 1997a, b).

2. A small stripe of units situated within the intensely deformed belt of the Mid-Hungarian fault zone (Fig. 1), whose Upper Paleozoic and Mesozoic cover (outcropping in the Bükk Mountains) has a marked affinity to the internal Dinarides (Kovács et al. 2000; Haas et al. 2000). These Dinaridic units also contain remnants of obducted ophiolites and oceanic accretionary prisms.

3. The Tisza block, located SE of the Mid-Hungarian fault zone and largely covered by the Neogene fill of the Pannonian basin, crops out in the North Apuseni mountains, as well as in a series of Hungarian and Croatian inselbergs. The paleogeographic position of the Tisza unit is much debated (e.g. Burchfiel 1980; Săndulescu 1984, 1994; Csontos et al. 1992; Balintoni 1995; Fodor et al. 1999; Haas and Pero 2004). Its Mesozoic cover with European as well as Apulian affinities suggests that it broke off Europe along an eastern extension of the Piedmont-Liguria basin in Mid-Jurassic times (Haas and Pero 2004; Stampfli and Borel 2004).

4. The Dacia block is a Europe-derived allochthon (or "Rhodopian" allochthon, Burchfiel 1980; Schmid et al. 1998; Fügenschuh and Schmid 2005), comprising the Balkan mountains, the Getides of the Southern Carpathians, as well as the Eastern Carpathian Bucovinian nappe system (Median
Dacides of Săndulescu et al. 1981; Săndulescu 1994). Some authors consider Tisza and Dacia as representing one single block (e.g. "Tisza-Dacia terrane" of Csontos and Vörös 2004) since the Late Cretaceous, but it is not yet sure as to how firmly Dacia remained attached to Tisza since the Mid-Cretaceous orogeny.

The development of the Carpathian orogen is also highly influenced by tectonic events within the Alps (Schmid et al. 2004a, b) and the Dinarides (Pamic 2000; Dimitrijevic 2001). Particularly the onset of "lateral extrusion", a mechanism defined by Ratschbacher et al. (1991a, b) in the Eastern Alps, is of major importance: Indentation by the South Alpine block, coupled to retreat of the descending European lithosphere (Royden 1988; Wortel and Spakman 2000), led to the ENE-ward translation of the ALCAPA block along the Insubric-Balaton line.

However, since the emplacement of Tisza and Dacia is unrelated to indentation in the Alps, subduction retreat is considered to provide the principal driving force for the invasion of the various blocks into the Carpathian embayment (Royden 1988; Wortel and Spakman 2000; Sperner et al. 2005). Furthermore subduction and retreat of the European plate beneath the inner Carpathians led to the formation of a backarc-type basin: the Pannonian basin (i.e. Horváth et al. 2005; Cloetingh et al. 2005). Net east-west extension in the Pannonian basin is realized by normal faulting connected via conjugate strike-slip dominated systems. 
These strike-slip systems are also kinematically linked to synchronous thrusting in the external Miocene thrust belt (Royden 1988).

Field-based studies in the West Carpathians shed light on the interplay between subduction retreat and "lateral extrusion" (e.g. Nemčok 1993; Ratschbacher et al. 1993; Sperner et al. 2002). These authors documented NE-ward displacement and counter-clockwise rotation of the ALCAPA block, guided by strike-slip zones oriented sub-parallel to the collision suture. NNE-SSW shortening and ESE-WNW extension were the dominant modes of deformation during Late Oligocene to Mid-Miocene NE-ward movement of ALCAPA. After soft collision of ALCAPA with the European margin in the Western Carpathians at around $13 \mathrm{Ma}$ ago, active subduction continued only further to the southeast, inducing NW-SE extension in the area of the Western Carpathians (Sperner et al. 2002).

The Mid-Hungarian fault zone played a key role during the emplacement of the various blocks in the Carpathian embayment. This major NE-trending strike-slip zone is thought to accommodate differential movements between ALCAPA and Tisza-Dacia (Fig. 1). It is bounded to the north by the Balaton line, the NE-wards continuation of the Periadriatic line (Fodor et al. 1998). The southern boundary of the MidHungarian fault zone is termed Mid-Hungarian line, defined as "a major strike-slip fault along which the ALCAPA and Tisza-Dacia units of different provenance were juxtaposed" by Csontos and Nagymarosy (1998). ALCAPA, Tisza and Dacia feature contrasting Triassic and Jurassic sedimentary facies and fossil assemblages (Csontos and Vörös 2004, and references therein). The first important activity within the MidHungarian fault zone occurred during the Oligocene (or earlier) (Csontos et al. 1992; Csontos and Nagymarosy 1998; Fodor et al. 1999). Thereby collision led to thrusting of the ALCAPA block over Tisza and Dacia in Late Oligocene times (Csontos and Nagymarosy 1998).

Corner effects at the Bohemian (Sperner et al. 2002) and Moesian (Ratschbacher et al. 1993; Schmid et al. 1998) promontories, respectively, led to opposed rotations well established by paleomagnetic studies (e.g. Márton and Fodor 1995, 2003; Márton 2000). While the timing of the emplacement of the ALCAPA block is fairly well constrained to have occurred between Late Oligocene and Middle Miocene times (Fodor et al. 1999; Sperner et al. 2002), emplacement of the Dacia (and Tisza?) block commenced earlier [during the Eocene according to Fügenschuh and Schmid (2005)], and ended later (in post-Middle
Miocene times, e.g. Matenco et al. 2003). During MidLate Miocene times (i.e. after $16 \mathrm{Ma}$ ) strike-slip deformation and extension dominated within the MidHungarian fault zone, allowing for ongoing differential movements of the ALCAPA and Tisza-Dacia blocks (Csontos and Nagymarosy 1998). During this late stage the Mid-Hungarian fault zone may also have served as a transfer zone between the foreland thrust belt and the back-arc extension domain. In conclusion, diverging movement vectors as well as large opposed rotations call for important and complex tectonic movements within the Mid-Hungarian fault zone all the way from Oligocene to Miocene times.

This study covers the outcropping parts of the MidHungarian fault zone at its NE termination in northern Romania (Fig. 1). The thrust contact of the so-called "Pienides" (Săndulescu et al. 1981), flysch nappes situated at the contact of the easternmost tip of ALCAPA with Tisza-Dacia, represents the Early Miocene Mid-Hungarian line sensu Csontos and Nagymarosy (1998) and is exposed in the study area. The Bogdan-Voda and Dragos-Voda strike-slip faults, as well as the Preluca fault near the northeastern rim of the Tisza block (Fig. 2), are first order candidates for representing surface exposures of the Mid-Hungarian fault zone that were active during Mid-Late Miocene times.

This study aims to provide further constraints on the timing and kinematics of movement along the MidHungarian fault zone during back-arc extension and final emplacement of the ALCAPA, Tisza and Dacia blocks. With the aid of published and unpublished (Săndulescu personal communication.) maps of the Geological Survey of Romania, our field-work focussed on the analysis of kinematic data and was assisted by apatite fission track analyses. Stratigraphic ages are after Gradstein et al. (2004), Mediterranean and Parathetys stages are correlated according to Steininger and Wessely (2000).

\section{Geological setting}

The study area, located in the internal East Carpathians (Northern Romania) near the transition to the Western Carpathians (Fig. 1), comprises the northeastern tip of the Tisza block (Biharia unit) and the northernmost part of Dacia (Bucovinian nappes). Alpine-age deformation within the Bucovinian nappes and the Biharia unit started in Mid-Cretaceous times ("Austrian" phase) and continued until Late Cretaceous times ("Laramide" phase, Săndulescu et al. 1981; Săndulescu 1994). Upper Cretaceous-Paleocene sediments unconformably cover these Mid- and Late-Cretaceous 
tectonic contacts, as well as contacts between Tisza, Dacia and intervening oceanic remnants (Fig. 1). Eocene-Burdigalian strata were deposited above a second unconformity. This mainly Tertiary cover is referred to as "autochthonous cover of Tisza-Dacia" in the following. During final closure of the Carpathian embayment, the Bucovinian nappes were emplaced onto Cretaceous-Miocene flysch deposits now forming the Miocene fold-and-thrust-belt of the East Carpathians.

Tisza and Dacia, together with their autochthonous cover, were overthrust by the Pienides during Burdigalian times (Săndulescu et al. 1981). According to Săndulescu et al. (1993) the Pienides, situated at the easternmost tip of ALCAPA, comprise an external (Petrova, Leordina and Wildflysch nappes) and an internal thrust sheet (Botiza nappe). Internal and external Pienides, mainly consisting of Eocene-Oligocene non-metamorphic flysch units, can be correlated with the Ivancovce-Krichevo units and the Magura flysch of the Western Carpathians, respectively (Săndulescu et al. 1981; Săndulescu 1994). Furthermore the internal Pienides feature frontal imbricates containing phacoids of Pieniny Klippen type material embedded in Eocene flysch (Săndulescu et al. 1993). Note that these units and their equivalents form the innermost part of the Outer West Carpathians (Plasienka et al. 1997a, b), while they take a more internal position in our working area.

The post-Burdigalian infill of the Pannonian and Transylvanian basins in the working area starts with the deposition of the Mid-Miocene (Badenian) Dej tuff during a period of mainly acidic volcanism (Mason et al. 1998). Subduction-related calc-alkaline magmatism (Mason et al. 1998) started during Middle Miocene times in the working area (13.5 Ma, Pécskay et al. 1995). Magmatic activity led to the formation of a linear chain along the inner side of the East Carpathians decreasing in age from $12 \mathrm{Ma}$ in the NW to $0.2 \mathrm{Ma}$ in the SE.

From a tectonic point of view the most obvious structure is the E-striking, predominantly left-lateral, Bogdan-Dragos-Voda fault system. The Bogdan-Voda fault to the west offsets the autochthonous cover of Tisza-Dacia, as well as the nappe pile of the Pienides,

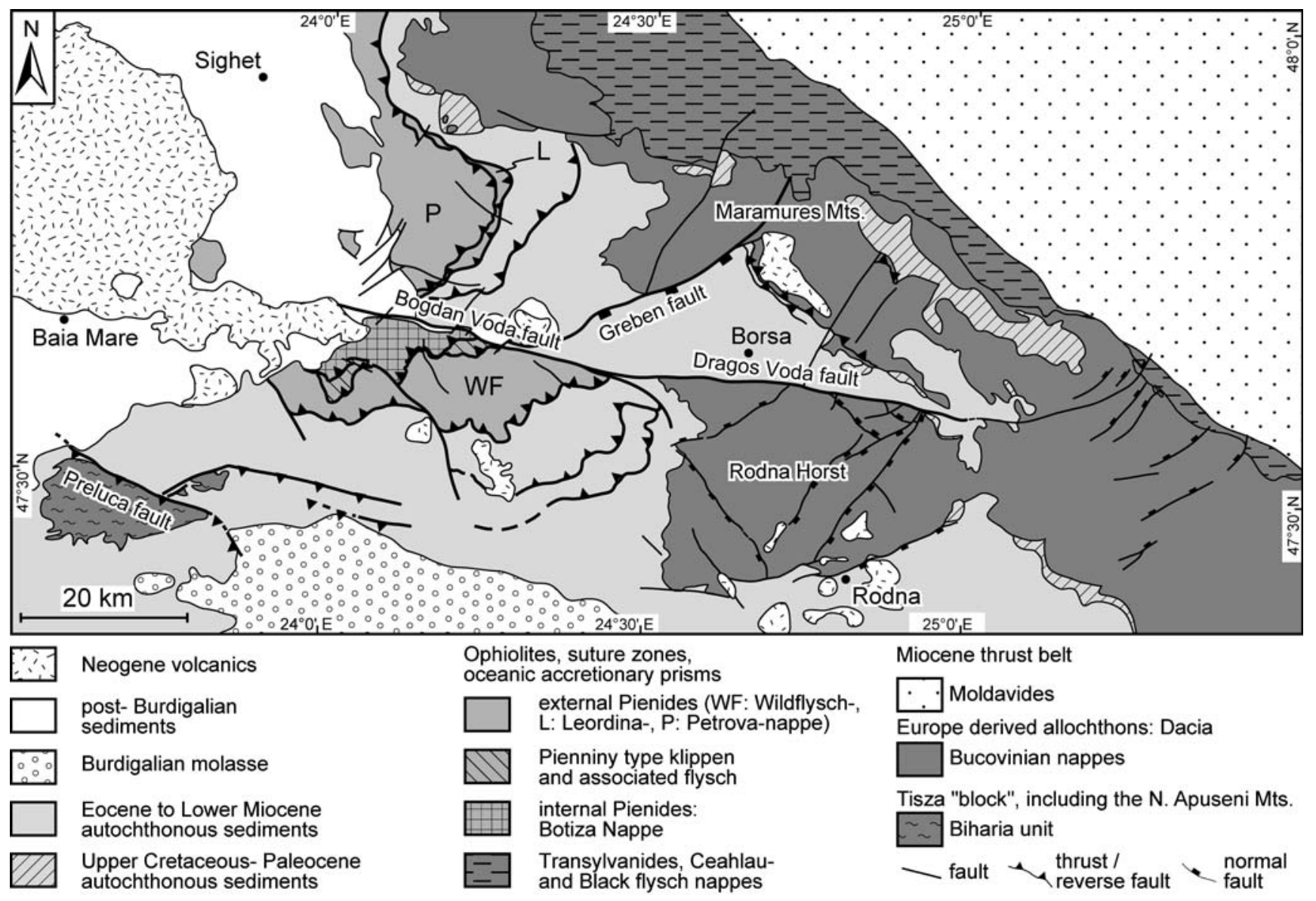

Fig. 2 Tectonic map of the study area based on published geological maps (1:50.000 and 1:200.000) of the Geological Survey of Romania, Dicea et al. (1980), Săndulescu (1980), Săndulescu et al. (1981) and Aroldi (2001) 
and is sealed by Mid-Miocene volcanics. The DragosVoda fault to the east forms the northern limit of a horst-like crystalline body ("Rodna horst", Fig. 2), built up by the Bucovinian nappe stack. Possible linkage of and mutual relationships between these two fault segments have been a point of discussion in the Romanian literature. While Săndulescu et al. (1981) interpreted the two faults as separate, Dicea et al. (1980) mapped a single continuous fault. Other authors (e.g. Huismanns et al. 1997, Györfi et al. 1999) mapped one single fault termed "Dragos-Voda fault".

\section{Methods}

\section{Derivation of kinematic axes}

Kinematic axes (principal shortening and extension directions) were derived from meso-scale structures in order to analyse the regional tectonic history. For this purpose, fault-slip sets (orientation of fault plane, sense and direction of movement) were analysed. Fieldwork focussed on correlation of the kinematic data with large-scale structures.

The direction of movement being given by a lineation (mechanical striation or slicko-fibre orientation), the sense of movement was determined by criteria such as slicko-fibre growth direction, orientation of Riedel shears or offset of marker horizons. Inhomogeneous data sets were separated into homogenous subsets based on field observations, and their kinematic compatibility (Fig. 3).
Kinematic axes were computed with the right dihedron method described by Angelier and Mechler (1977). Applicable to newly formed, as well as to reactivated pre-existing fractures, this simple graphical method reflects the bulk finite strain state (Pfiffner and Burkhard 1987). Eigenvectors and Eigenvalues (Bingham 1964) have been used to determine mean axes of shortening and extension (Fig. 3). A tabular overview on the analysed stations is found in Appendix 1. For calculation of kinematic axes and visualisation of fault sets we used the software TectonicsFP (Franz Reiter and Peter Acs@1996-2000: http://www.go.to/TectonicsFP; based on TectonicVB by Hugo Ortner).

Fission track analysis

Apatite mineral concentrates were prepared by conventional crushing, sieving, magnetic and heavy liquid separation. The grains were mounted in epoxy resin, polished and etched for $40 \mathrm{~s}$ at room temperature in $6.5 \%$ HNO3. Samples were analysed using the external detector method (Gleadow 1981), with muscovite as an external detector. Irradiation was carried out at the High Flux Australian Reactor with neutron fluxes monitored in CN5. Muscovite was etched $40 \mathrm{~min}$ at room temperature in $40 \% \mathrm{HF}$.

Fission tracks were counted on a computer-controlled Zeiss microscope at magnifications of X1250 (dry). Ages were calculated using the zeta-calibration method (Hurford and Green 1983) with a zeta-value of $355.96 \pm 9.39(\mathrm{CN} 5$, Durango). For data processing the
Fig. 3 Flow chart for the analysis of fault-slip data. For the separation of homogenous subsets field observations as well as kinematic

compatibility have been used. Kinematic compatibility has been assessed using plots of the fault sets and correspondent incremental strain axes (Marret and Allmendinger 1990). For map display mean axes of shortening and extension are used. Intersection relationships in the analysed outcrop show exemplary, that transpression was followed by transtension during the post Burdigalian stages

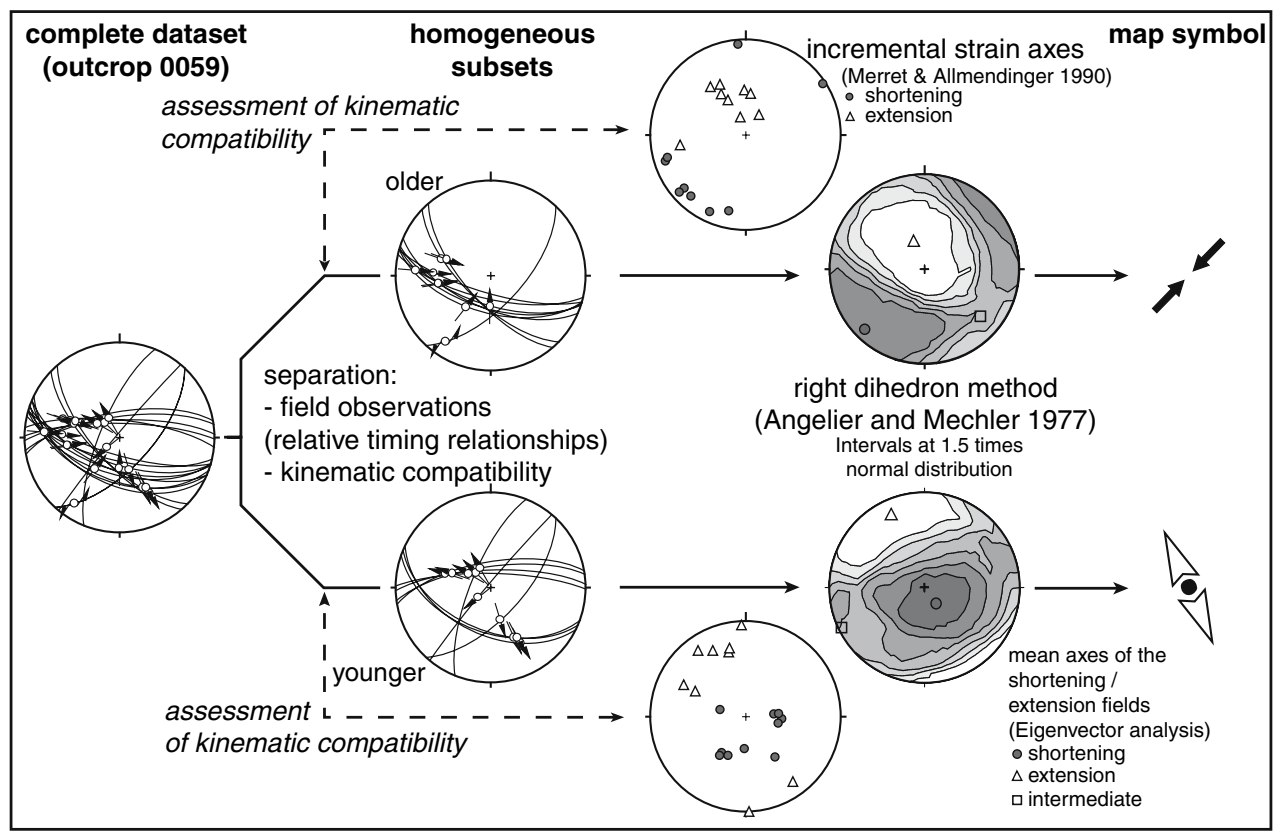


windows software TRACKKEY (Dunkl 2002) was used. All ages are central ages (Galbraith and Laslett 1993), with errors quoted as $1 \sigma$. Closure temperatures for apatite are $90 \pm 30^{\circ} \mathrm{C}$, the uncertainty being given by the lower and upper limits of the apatite fission track partial annealing zone (Gleadow and Duddy 1981; Gallagher et al. 1998).

\section{Structural analysis}

Early Burdigalian top-SE thrusting of the Pienides

The emplacement of the Pienides during Burdigalian times (Fig. 2) also led to the imbrication of the autochthonous cover of Tisza-Dacia. Deformation
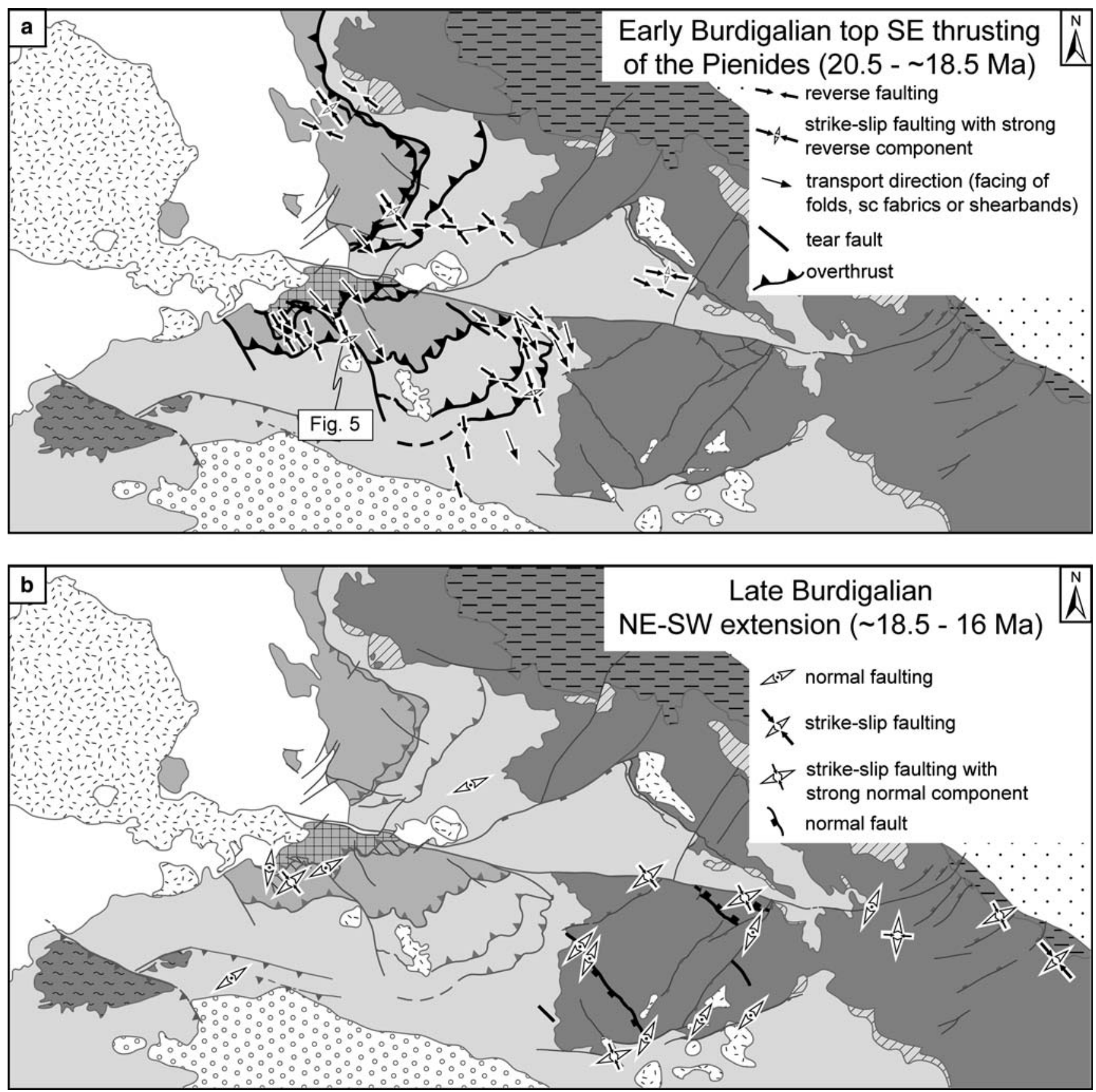

Fig. 4 Kinematics and structures related to the Burdigalian deformation phases. a Early Burdigalian emplacement of the Pienides shows consistent top-SE thrusting. The pronounced bends in the nappe front are interpreted as a result of a change in thrust geometry featuring frontal and lateral ramps as well as tear faults (see text). b Subordinate NE-SW extension, related to SE-striking normal faults of Late Burdigalian age 
related to the emplacement of the Pienides is primarily controlled by the more incompetent silty-marly flysch units, which are serving as detachment horizons. The more massive sandy layers only display moderate brittle deformation, even close to nappe contacts. Cataclastic shear zones related to nappe emplacement are the predominant deformation features, while folding is only locally developed. Within marly layers shear-bands and/or SC-type fabrics can locally be observed. The shortening direction related to the emplacement of the Pienides was evaluated by kinematic analysis of mesoscale faulting found near major cataclastic shear zones. Transport direction was inferred from the facing direction of outcrop-scale folds and/or SC-type fabrics and shear-bands.

The deduced kinematic directions (Fig. 4a) reveal a consistent displacement direction towards the SE (Appendix 2), both for the Pienides as well as for the imbricates of the autochthonous cover of Tisza-Dacia. The relative timing of fault sets found in two outcrops (Appendix 2, stations 0639, 0584) suggests a possible minor change in transport direction from top-SE towards top-ESE.

The frontal thrust of the Pienides has an extremely variable trace in map view (Fig. 4a), showing alternating SW- and SE-striking segments. Outcrops along the northernmost SE-striking thrust segment (Fig. 4a) expose SSE-striking strike-slip fault zones with a significant reverse component. The predominantly transpressional deformation encountered along this segment (Appendix 2, Station 0639), suggests a lateral ramp geometry. The thrust front of the Pienides south of the Bogdan-Voda fault shows three major sharp bends in map view (Fig. 4a). At one of the bends a steeply dipping dextral strike-slip fault zone, sub-parallel to the transport direction (Fig. 5), is interpreted as a tear fault. The increase of shortening within the autochthonous cover of Tisza-Dacia, observed in front of the Pienides towards the northeast, is a map-scale argument in favour of this interpretation.

The timing of Pienide nappe emplacement and related structures is constrained by stratigraphic arguments. The youngest thrusted strata are Aquitanian in age (Dicea et al. 1980), and thrust contacts are sealed by Badenian-age (16 to $13 \mathrm{Ma}$ ) sediments. Hence, an intra-Burdigalian activity can be inferred. The fact, that structures related to Late Burdigalian extensional deformation (see below) overprint nappe emplacement features, allows us to suggest an Early Burdigalian (20.5- 18.5 Ma) age for the emplacement of the Pienides.

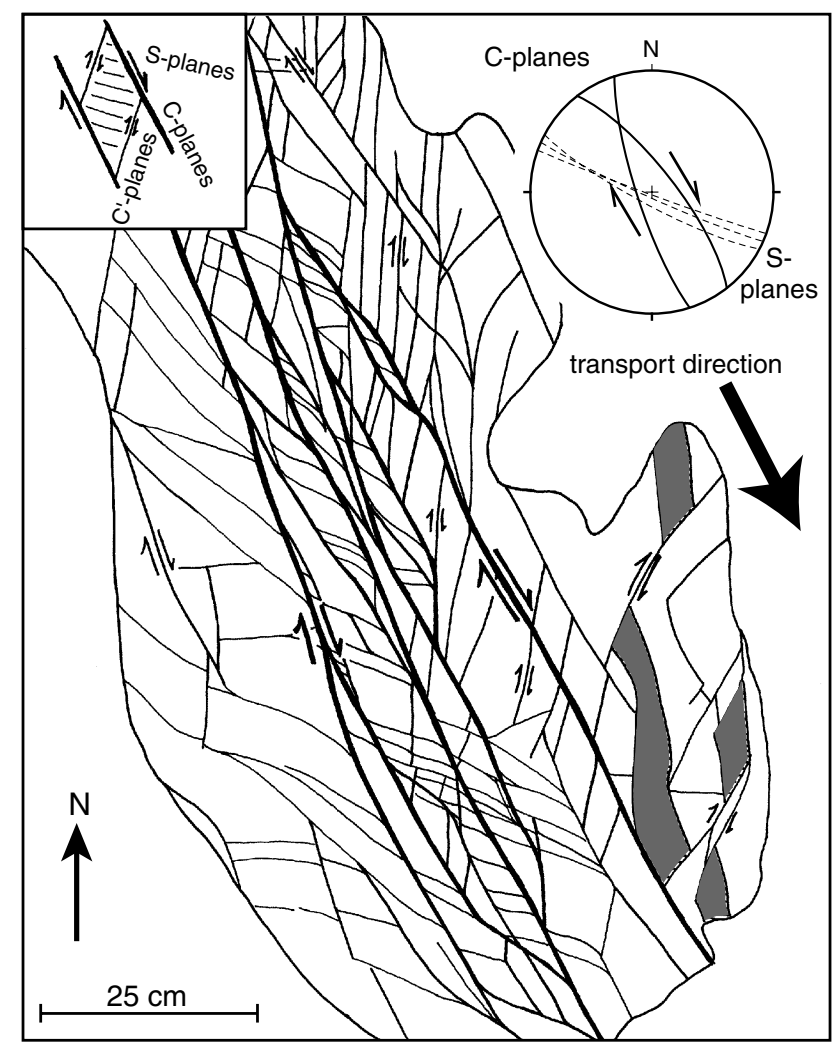

Fig. 5 Outcrop sketch (map view) of a cataclastically deformed fault zone at the NW-SE striking nappe contact of the Pienides against the autochthonous cover of Tisza-Dacia (see Fig. 4a). The fine-grained siliciclastics (homogenous clay rich silts) are dissected by anastomosing shear zones featuring shear band geometries. Shaded areas indicate offset of silty marker horizons. The strike-slip dominated kinematics confirm the interpretation of the NW-SE striking contacts as tear faults

\section{Late Burdigalian NE-SW extension}

While SE-trending normal faults are rarely observed in the sedimentary cover, they are more abundant within the basement units of the study area. The most prominent of these SE-striking faults are found within the SW part of the Rodna massif (Fig. 4b), where they offset Bucovinian-type basement as well as Oligocene strata. Kinematic analysis of these faults yielded NE-SW to NNE-SSW extension, i.e. normal faulting with a minor strike-slip component (Fig. 4b; Appendix 3).

Field evidence clearly suggests that these normal faults overprint structures related to the emplacement of the Pienides (e.g. Station 0236, Appendix 2, 3). Since structures of this phase are cut by the Dragos-Voda fault while Badenian (16 to -13 Ma) strata are unaffected, we assume a preBadenian (18.5 to $16 \mathrm{Ma}$ ) age for this extensional deformation. 
Post-Burdigalian structures

Emplacement of the Pienides was post-dated by extensive faulting. Strike-slip activity along the Bogdan-Dragos-Voda fault system can be subdivided into an earlier transpressional stage followed by transtension.

\section{Transpressional stage}

Open folds with SE- to ESE-striking fold axes (Fig. 6a) evidence post-Burdigalian shortening in the sedimentary units of the study area. Wavelengths of these folds range between outcrop-scale up to several hundreds of meters. While fold limbs are only weakly inclined
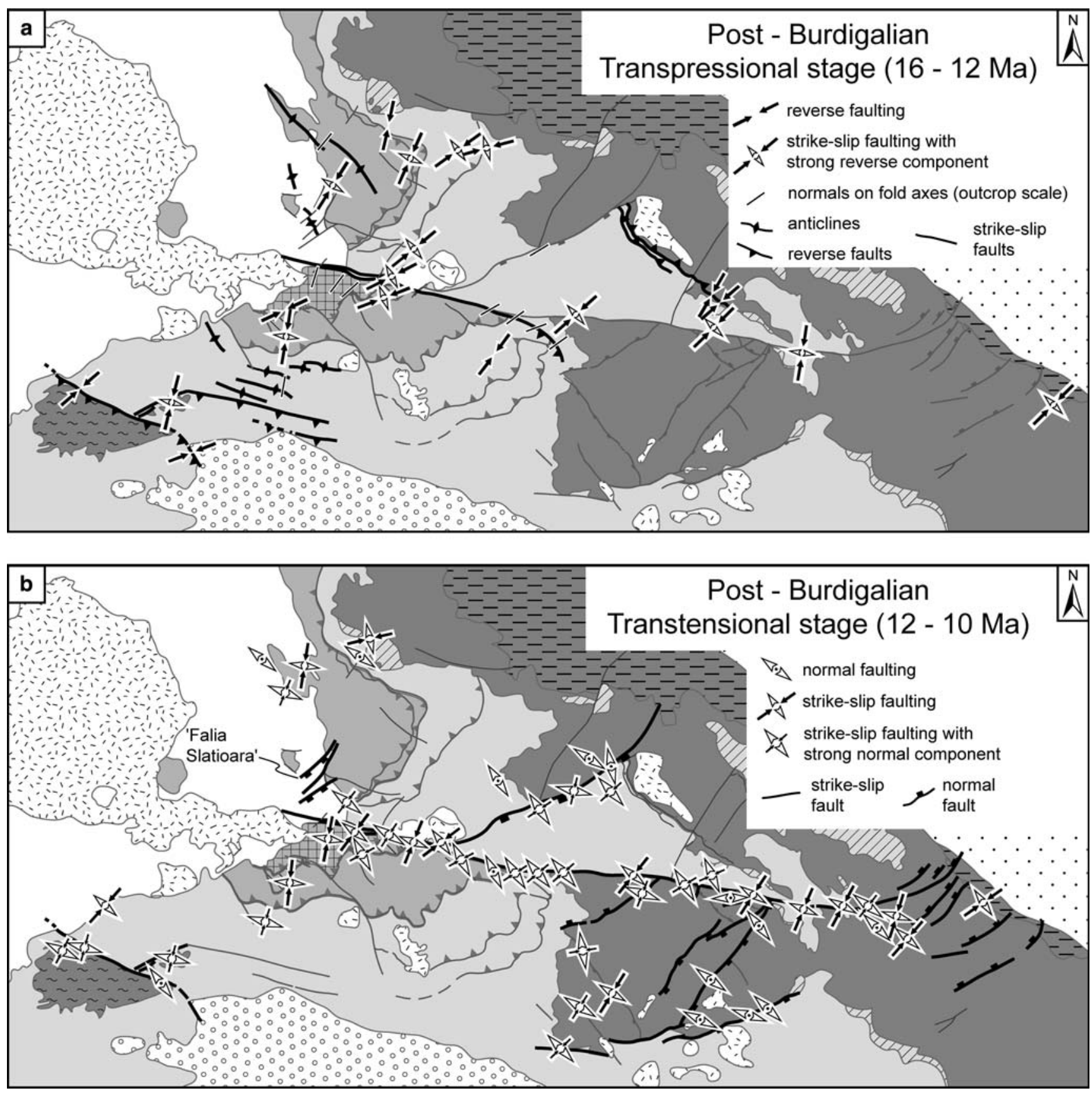

Fig. 6 Kinematics and structures related to the post-Burdigalian (16 to $10 \mathrm{Ma}$ ) activity of the Bogdan- and Dragos-Voda faults. Transpression (a) preceeds transtension (b). Shortening is
SW-NE during both phases. Note the linked Bogdan-Voda and Dragos-Voda fault activity during the transtensional stage 
Fig. 7 Schematic block diagram of an outcrop showing the overprinting of nappe emplacement structures. The tight asymmetric folds developed during nappe emplacement (left and right) are refolded by an upright open fold with SEtrending fold axis. Such folds are related to the post Burdigalian transpressional stage and can be found throughout the study area

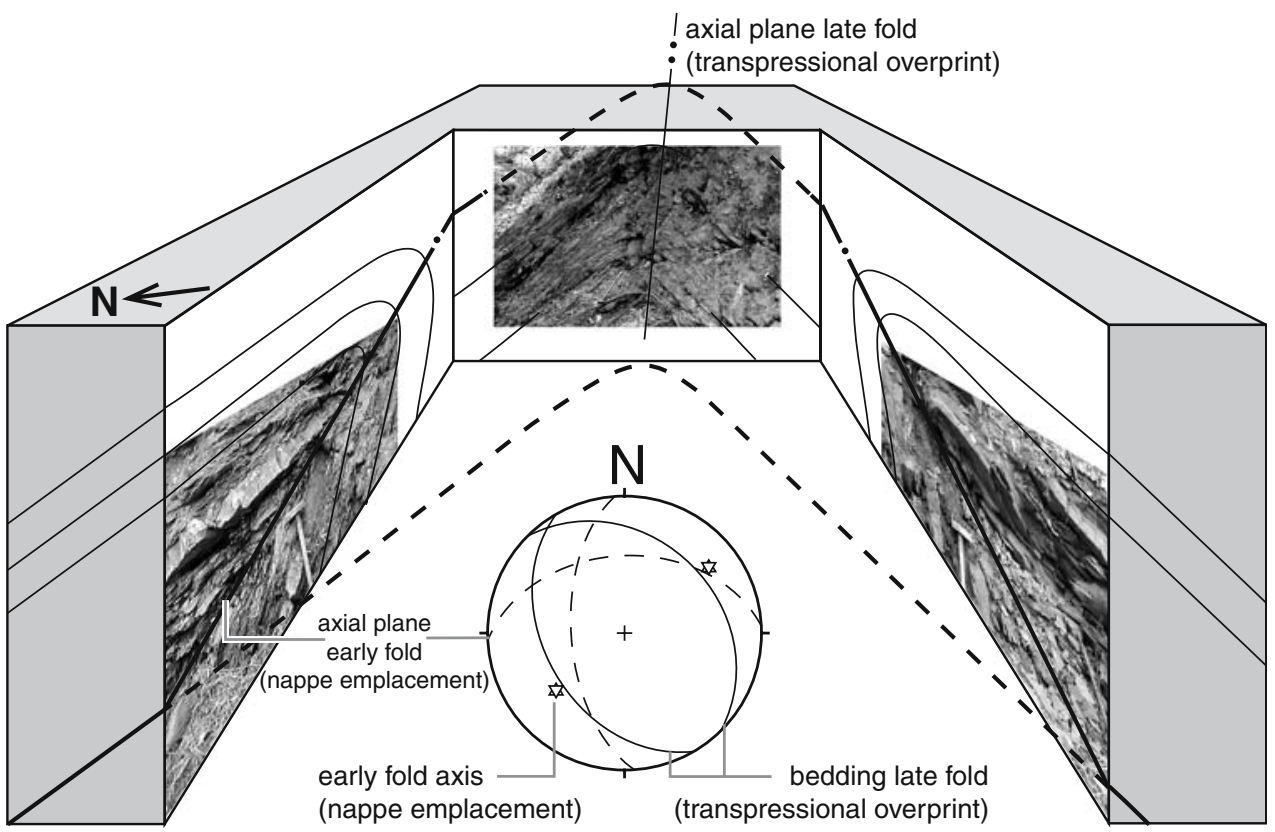

south of the Bogdan-Voda fault, they reach dip angles of up to $50^{\circ}$ in the north. These SE- to ESE-striking folds overprint earlier nappe emplacement structures (Fig. 7). Approaching the fault trace of the BogdanVoda fault, this late-stage folding locally intensifies, which leads to isoclinal folding around steeply inclined fold axes.

Faulting with a strong reverse component is found throughout the study area and is documented in map scale (Fig. 6a), as well as in outcrop scale (Appendix 4). The most dominant types of structures are SE-striking reverse faults (e.g. back-thrust E of Borsa, Appendix 4, Station 0809; Preluca fault, Appendix 4, Station 0259), as well as E-striking transpressional faults (e.g. the Bogdan-Voda fault; Appendix 4, Stations 0682, 0675). During this transpressional phase the Bogdan-Voda fault terminates at the Rodna horst in a thrust splay geometry.

In summary, the kinematic analysis yields transpression with NE-SW shortening and minor NW-SE extension.

\section{Transtensional stage}

E-trending strike slip faults (e.g. Bogdan-DragosVoda fault system) as well as SW-striking normal faults (e.g. Greben fault) can be attributed to the transtensional stage (Fig. 2). Deformation found along and associated with the Bogdan-Voda and Dragos-Voda faults is dominated by sinistral strikeslip faulting often featuring a normal component.
Striations plunge about $5-15^{\circ}$ to the west along the Bogdan-Voda fault and up to $20^{\circ}$ along the DragosVoda fault (Appendices 5,6). These strike-slip faults are commonly accompanied by sets of SW-striking normal faults (Appendices 5, 6).

The E-trending strike slip faults as well as SW-striking normal faults yield regionally consistent kinematic axes. The extensional axes are oriented sub-horizontally NW-SE. Shortening axes strike SW, with dip angles depending on the relative amount of the normal and strike-slip components respectively.

Near its eastern termination, the Bogdan-DragosVoda fault system splays into an array of SW-trending normal faults with a left-lateral component. These "horsetails", which accommodated only minor displacements, allowed for "distributed" sinistral offset. This is reflected by the lack of a map-scale discrete offset of major pre-existing tectonic boundaries, such as the front of the Bucovinian nappes (Fig. 2). Kinematic axes derived for these SW-NE trending normal faults are compatible with those derived for the Bogdan-Dragos-Voda fault system (Fig. 6b, Appendix 5). Sinistral transtension is further documented along the Preluca fault, where it overprints a preceeding phase of top NE thrusting (Fig. 6b, Appendix 6).

Stratigraphical timing constraints regarding post-Burdigalian deformation

The formation containing the Lower Badenian Dej tuff represents an ideal marker horizon in the 
northern part of the study area. Post-dating Burdigalian age deformation, it is affected by both the transpressive and transtensive stages along the Bogdan-Voda and the Dragos-Voda fault and hence provides a lower time bracket of $16 \mathrm{Ma}$ (i.e. onset of the Badenian). The Preluca fault also shows post $16 \mathrm{Ma}$ activity, indicated by Burdigalian strata affected by NE-SW shortening (Appendix 4, Station 0260).

The upper time bracket of post-Burdigalian deformation is well defined by the Neogene volcanic body near Baia Mare (Fig. 2). The $10 \mathrm{Ma}$ old volcanics constituting the main body (Pécskay et al. 1995) seal the Bogdan-Voda fault (Fig. 2).

Overprinting criteria observed at outcrop and map scales indicate that transpression was followed by transtension. For example the SE-striking back-thrust east of Borsa is cut by the younger Greben normal fault (Fig. 6). The timing of the change from transpression to transtension is derived from Antonescu et al. (1981). These authors map SW-trending faults (e.g. "Falia Slatioara", Fig. 6b) which are cutting strata younger than $\sim 12.2 \mathrm{Ma}$ (Lower Bessarabian in Antonescu et al. 1981). Since the strike of the faults

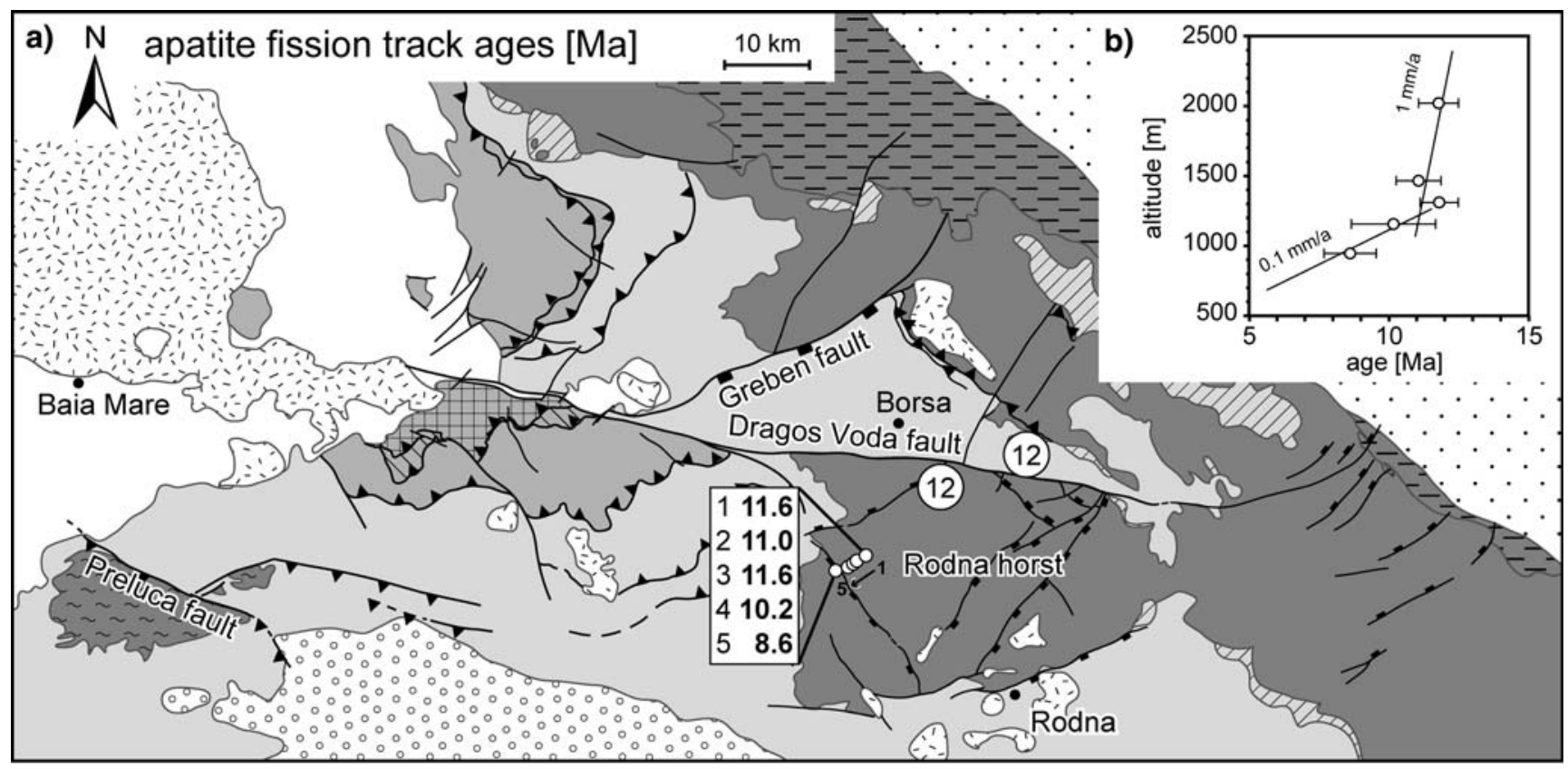

c)

\begin{tabular}{cccccccc}
\hline $\begin{array}{c}\text { sample } \\
\text { code }\end{array}$ & $\begin{array}{c}\text { altitude } \\
{[\mathrm{m}]}\end{array}$ & $\begin{array}{c}\text { No. grains } \\
\text { counted }\end{array}$ & $\begin{array}{c}\text { standard track densities } \\
\times 10^{5} \mathbf{c m}^{-2} \text { (counted) }\end{array}$ & $\begin{array}{c}\text { Ps } \times 10^{5} \mathbf{c m}^{-2} \\
\text { (counted) }\end{array}$ & $\begin{array}{c}\text { Pi } \times 10^{5} \mathrm{~cm}^{-2} \\
\text { (counted) }\end{array}$ & $\begin{array}{c}\chi^{2} \\
{[\%]}\end{array}$ & $\begin{array}{c}\text { age }[\mathrm{Ma}] \\
\pm 1 \sigma\end{array}$ \\
\hline 1 & 2020 & 24 & $9.78(4451)$ & $4.41(539)$ & $65.71(8030)$ & 8 & $11.6 \pm 0.7$ \\
2 & 1465 & 20 & $13.04(4766)$ & $2.55(357)$ & $54.69(7646)$ & 10 & $11.0 \pm 0.8$ \\
3 & 1310 & 20 & $12.79(4766)$ & $2.48(496)$ & $48.58(9716)$ & 13 & $11.6 \pm 0.7$ \\
4 & 1155 & 20 & $12.54(4766)$ & $0.38(50)$ & $8.30(1096)$ & 99 & $10.2 \pm 1.5$ \\
5 & 945 & 20 & $8.17(4223)$ & $0.94(111)$ & $15.89(1873)$ & 79 & $8.6 \pm 0.9$ \\
\hline
\end{tabular}

Fig. 8 Results of apatite fission track analyses. All samples were analysed using the external detector method (Gleadow 1981) and ages were calculated using the zeta-calibration method (Hurford and Green 1983) on the base of the Durango standard with a zeta value of $355.96 \pm 9.39$ a Tectonic map showing apatite fission track data. Samples labelled with circles are from Sanders (1998). b Altitude versus age diagram of the apatite fission track ages. The ages show relatively fast exhumation (at least $1 \mathrm{~mm} / \mathrm{a}$ ) between 12 and $11 \mathrm{Ma}$ followed by slow exhumation (around
$0.1 \mathrm{~mm} / \mathrm{a}$ ) after $10 \mathrm{Ma}$. c Table regarding the apatite fission track data. Column 1 gives the sample code, column 2 the altitude above sea level, column 3 the number of dated grains. Columns 4, 5 and 6 show standard, spontaneous and induced track densities, respectively, and the number of counted tracks in brackets. Column 7 gives Chi-square probability (Galbraith 1981) and column 8 apatite fission track central ages (Galbraith and Laslett 1993), which are the weighted mean of the single grain ages 
mapped by Antonescu et al. (1981) is compatible with normal faults related to the transtensional stage, we infer the onset of transtension to have commenced at around $12 \mathrm{Ma}$ ago.

\section{Constraints from fission track data}

Due to the lack of stratigraphical timing constraints along the Dragos-Voda fault, its activity was indirectly dated by inferences from the cooling history of the syn-kinematically exhumed Rodna horst (Fig. 8). A vertical profile covering about $1,000 \mathrm{~m}$ of altitude difference has been sampled for apatite fission track analysis (5 samples). The uppermost sample is taken close to the projected basal unconformity of the overlying Tertiary sediments. The presented samples have been selected from a larger set of data that is discussed in more detail in Gröger (2006).

Burial by Eocene to Lower Miocene sediments led to total annealing of fission tracks in all samples, as evidenced by the fact that all samples passed the Chi-square test (Fig. 8c; $X^{2}>5 \%$ ). Subsequent cooling through the apatite fission track annealing zone yielded Middle to Late Miocene cooling ages (11.6 to 8.6 Ma; Fig. 8), where the youngest ages are found at the lowest altitudes of the profile. The three uppermost samples span $710 \mathrm{~m}$, but yield similar ages (11.6, 11.0 and 11.6 Ma). A significant decrease in age can only be observed in the two lowermost samples (10.2 and 8.6 Ma). The altitude versus age relationship thus suggests enhanced exhumation between 12 and $11 \mathrm{Ma}$ with exhumation rates of at least $1 \mathrm{~mm} / \mathrm{a}$. After $10 \mathrm{Ma}$ the rate of exhumation decelerates to around $0.1 \mathrm{~mm} / \mathrm{a}$ (Fig. $8 \mathrm{~b}$ ). Our data are in agreement with data by Sanders (1998), also depicted in Fig. 8a.

The enhanced cooling of the Rodna horst through the apatite partial annealing zone between 12 and $11 \mathrm{Ma}$ is interpreted to be caused by fault-bounded exhumation in the footwall of the sinistral transtensive Dragos-Voda fault. This indirect dating of the transtensional stage based on apatite fission track analysis is consistent with stratigraphical timing constraints (12-10 Ma, see above) for transtension along the Bogdan-Voda fault. The concurrent time constraints, independently derived, support the conclusion that the Bogdan-Voda and Dragos-Voda faults acted as a single continuous fault during this second transtensional stage. Additionally, the apatite fission track data corroborate that the transtensional stage between 12 and $10 \mathrm{Ma}$ represents the main phase of activity along the Dragos-Voda fault.

\section{Synthesis of data}

Burdigalian thrusting of the Pienides followed by NE-SW extension

Analysis of the structures related to the Burdigalianage emplacement of the Pienides consistently yielded top-SE transport (Fig. 4a). Thrusting of the Pienides and within the autochthonous cover of Tisza-Dacia was coeval, as indicated by stratigraphic timing criteria corroborated by our kinematic analyses. A change from top-SE to top-ESE transport, as suggested by two of the studied outcrops, could not be consistently documented for the study area.

At first sight, the constant displacement directions inferred for the thrusting of the Pienides is in contradiction to the extremely variable trace of the frontal thrust in map view. The most likely explanation for the arcuate shape of the Pienide nappe contact is a laterally changing thrust plane geometry, with SW striking frontal ramps alternating with SE-striking tear faults and/or lateral ramps.

Although SE-striking normal faults, generated by a phase of SW-NE extension, are found throughout the study area, they are more abundant in the basement rocks of the Rodna horst (Fig. 4b) than in the Oligocene sediments. The age of this normal faulting is inferred as Late Burdigalian.

Post-Burdigalian faulting along the Bogdanand Dragos-Voda faults

Our observations indicate a significant component of shortening during the earlier stage of left-lateral strike-slip movements along the Bogdan-Voda fault, which terminated towards the east along a SE striking thrust-splay, as mapped by Săndulescu (1994) and Dicea et al. (1980). Due to the scarcity of evidence for coeval transpressive deformation along the Dragos-Voda fault, we regard its role during this earlier stage of the post-Burdigalian deformation as subordinate. Hence, the two fault segments were not yet linked, and much of the offset along the BogdanVoda fault was taken up by thrusting along its eastern termination. In the eastern part of the study area (near Borsa), a SE-trending back-thrust represents the major feature formed during this transpressive post-Burdigalian stage (Fig. 6a). The differences in deformational style between west and east may be due to earlier structures, particularly to the presence of a basement high in the area of the Rodna horst. This horst already existed during the Eocene. While the shallow marine Iza limestone formed on the 
Rodna horst, the pelagic sediments of the Vaser Formation were deposited north of it (Săndulescu et al. 1991; Kräutner et al. 1982). During the subsequent sinistral-transtensive stage the Bodgan-Voda and Dragos-Voda faults were kinematically linked; they acted as a single Bogdan-Dragos-Voda fault system, as mapped by Dicea et al. (1980). This is confirmed by structural and kinematic data and is also very evident from map-view. Additionally, intensely faulted outcrops situated at the junction between the two segments yield similar kinematics (Appendices 5, 6, Stations 0462, 0481, 0079) further corroborate this interpretation.

Since the major SW-trending normal faults within the Rodna horst and in the Maramures Mountains (i.e. the Greben fault) are kinematically compatible with this sinistral-transtensive activity along the Bogdan-Dragos-Voda fault system, we regard their activity as contemporaneous. The transtension along the Bogdan-Dragos-Voda fault system led to final cooling and exhumation of the Rodna horst from $12 \mathrm{Ma}$ onwards, as indicated by apatite fission track data. Towards the east, the net left-lateral offset along the Bogdan-Dragos-Voda fault system decreases due to the distribution of deformation into a horse-tail like array of SW-trending normal faults. At the contact of the inner East Carpathians with the Miocene thrust belt of the Moldavides the localised offset diminishes to almost zero. Transtension also affected the southeastern part of the study area, where the entire Rodna horst is affected and partly bounded by SW-striking normal faults (Fig. 6b; Appendix 6). Subordinate reactivation by transtension is also observed along the Preluca fault.

Estimates of horizontal and vertical components of displacement across the Bogdan-Voda and Dragos-Voda faults

Since movement along the Bogdan-Voda fault segment accumulated during two stages, we first evaluate the offsets along the Dragos-Voda fault, which was essentially active only during the later transtensive stage.

Based on published maps (Geological Survey of Romania) and stratigraphic logs of the sediments juxtaposed against the crystalline basement units (Dicea et al. 1980) the south-side-up vertical offset across the Dragos-Voda fault south of Borsa (Fig. 2) can be estimated to reach $2 \mathrm{~km}$. Assuming that the average measured pitch of striations at the DragosVoda fault of $15^{\circ}$ (Appendices 5, 6) indicates the movement vector during transtension, the horizontal displacement had to be in the order of $7 \mathrm{~km}$.

Since offset along the Dragos-Voda fault continuously decreases from west to east due to coevally active SW-trending normal faults, the offset for a specific point can be estimated by a simple linear interpolation using the previously mentioned displacement estimates together with the horizontal distance between Borsa and the point of negligible offset at the horsetail splay.

Thus the maximum offset of the Dragos-Voda fault segment, accumulated in its westernmost part, can be estimated to reach values in the order of $11 \mathrm{~km}$ (horizontal) and $3 \mathrm{~km}$ (vertical), respectively. For the eastern part of the Rodna horst our linear approach predicts a vertical offset in the order of $1 \mathrm{~km}$. Apatite fission track ages from this region (Sanders 1998) are identical on either side of the Dragos-Voda fault (Fig. 8), thus also indicating minor (i.e. $<1 \mathrm{~km}$ ) vertical displacement below data resolution.

A total lateral offset of about $25 \mathrm{~km}$ for the BogdanVoda fault can be deduced from the left-lateral offset of the Pienide thrust front (Fig. 2). The north side down component is evidenced by the relative offset of the post-Burdigalian strata (Fig. 2). From the shallow plunge of lineations observed at the Bogdan-Voda fault ( $5^{\circ}$ west), a total vertical offset of about $2.5 \mathrm{~km}$ is obtained. Using the estimate of total lateral offset along the Dragos-Voda fault (see above), we infer that at least $11 \mathrm{~km}$ lateral and $1 \mathrm{~km}$ vertical offset were produced during the transtensional stage.

It should be noted, that the marked difference in vertical offsets between the Bogdan-Voda fault segment $(1 \mathrm{~km})$ and Dragos-Voda fault segment $(3 \mathrm{~km})$ during the transtensional stage is accommodated by the SW-trending Greben fault. Based on published geological maps (Geological Survey of Romania), the vertical offset at the Greben fault is estimated to reach about $2 \mathrm{~km}$.

\section{Discussion of earlier work and large-scale correlations}

Comparison with previous data from the working area

Our observations and conclusions are largely comparable to a previous study in this area carried out by Györfi et al. (1999). However, we consider SW-NE shortening to be post-Burdigalian rather than Oligocene in age. Györfi et al. (1999) correlated the Late Miocene activity of the Bogdan-Dragos-Voda fault system with extensional features of Early Pannonian 
( $~ 9$ to $11.8 \mathrm{Ma}$ ) age described in seismic studies from the Pannonian basin. This time frame is compatible with our timing estimates for the transtensional stage (12 to $10 \mathrm{Ma}$ ).

The conclusions of Huismans et al. (1997) strongly differ from our interpretation. The major difference to our study is that we regard the Early Burdigalian emplacement of the Pienides as top-SE directed rather than due to NNE-SSW compression. We partly disagree with Ciulavu (1999), who argued that extensional veins filled by hydrothermal ore deposits, dated to $8.7 \pm 0.4 \mathrm{Ma}$ (Pécskay et al. 1994) and found within the volcanic body of Baia Mare, point towards a post-10 Ma activity of the Bogdan-Voda fault. On the available maps the pyroxene andesites (10.110.9 Ma, Pécskay et al. 1994), constituting most of the volcanic body of Baia Mare, are not crosscut by the Bogdan-Voda fault. Hence we conclude, that major activity along the Bogdan-Dragos-Voda fault system ceased at some $10 \mathrm{Ma}$ ago, while the mineralized veins indicate partial reactivation of minor importance only.

Burdigalian top-SE thrusting of the Pienides followed by NE-SW extension in the larger scale context

Based on seismic studies located in central Hungary Csontos and Nagymarosy (1998) report Oligocene to Lower Miocene-age thrusting of ALCAPA onto Tisza-Dacia along the Mid-Hungarian line. In agreement with Csontos and Nagymarosy (1998) and Csontos and Vörös (2004) we consider the Pienide nappe contact as representing the eastward continuation of the Mid-Hungarian fault zone during Burdigalian times. Since the Pienides are correlated with parts of the Western Carpathians (Săndulescu et al. 1981; Săndulescu 1994), i.e. with units that are clearly part of what is commonly referred to as "ALCAPA", they are considered to represent the easternmost tip of ALCAPA.

Many authors postulate a significant (in the order of $90^{\circ}$ ) clockwise rotation of Tisza-Dacia during its Mid-Miocene emplacement (e.g. Fodor et al. 1999, Márton and Fodor 2003). Such rotations should cause progressive reorientation of earlier formed structures (i.e. our nappe emplacement structures) as they are passively rotated together with the Tisza-Dacia block. However, we observed no regionally consistent evidence for such a change in transport directions. Thus we conclude that a major part of the rotation commenced earlier, possibly in the Early Oligocene, as is discussed in Györfi et al. (1999). This would imply that shortening across the Mid-Hungarian fault zone (Csontos and Nagymarosy 1998) and the emplacement of the Pienides in northern Romania only reflect the last stage of the juxtaposition of the ALCAPA and Tisza-Dacia blocks, a process that initiated much earlier (Csontos and Nagymarosy 1998). Comparable to the Late Burdigalian ( 18.5 to $16 \mathrm{Ma}) \mathrm{NE}-\mathrm{SW}$ extension documented in this study, Csontos and Nagymarosy (1998) report Early to MidMiocene extension within the Pannonian basin i.e. also along the Mid-Hungarian fault. Fodor et al. (1999) interpret NE-SW extension (17 to $15 \mathrm{Ma})$ within the Pannonian basin system as being related to back arc extension in the context of subduction rollback in the Carpathians.

In conclusion, we regard Early Burdigalian top-SE thrusting of the Pienides, i.e. the easternmost tip of ALCAPA, to be related to transpression along the Mid-Hungarian fault zone in the context of lateral extrusion of ALCAPA. Subsequent Late Burdigalian NE-SW-directed extension marks the extensional overprint of the Tisza-Dacia block due to ongoing rollback in the northernmost East Carpathians.

Post-Burdigalian activity along the Bogdan-DragosVoda fault system in the larger scale context

While subduction rollback migrates eastwards due to propagating slab detachment (Wortel and Spakman 2000) convergence in the western Carpathians comes to a halt and most likely leads to a pronounced change in deformational style along the Mid-Hungarian fault zone (Fodor et al. 1999). Late Badenian to Sarmatian (14 to $11 \mathrm{Ma}$ ) NW-SE extension in the Pannonian basin (Fodor et al. 1999) is interpreted as a period of left lateral transtension along the MidHungarian fault zone (Csontos and Nagymarosy 1998).

The left-lateral activity of the Bogdan-Voda and Dragos-Voda faults (16 to $10 \mathrm{Ma}$ ) coincides with this phase of sinistral transtension along the Mid-Hungarian fault zone and suggests a direct kinematic link between all these faults during this time interval. We suggest that the differing kinematics in our working area-transpression followed by transtension-may be explained by the "docking" of Tisza-Dacia with the European foreland. Starting in Late Burdigalian times, NE-directed thrusting of the Miocene thrust belt (Mat enco and Bertotti 2000) led to "soft collision" of TiszaDacia with the European foreland in the East Carpathians between some 16 and $10 \mathrm{Ma}$ ago. This scenario is comparable to the Western Carpathians, where Sperner et al. (2002) correlate NNE-SSW compression 
(dated by these authors as Oligocene (?) to Mid-Miocene) with "soft collision" between ALCAPA and the European continent. Final emplacement of the northern part of Tisza-Dacia induces the change towards the transtensional activity along the Bogdan-Dragos-Voda fault system. This transtensional stage is coeval to Late Sarmatian strike-slip activity in the external Miocene thrust belt of the East Carpathians (Matenco and Bertotti 2000).

Our data indicate a direct kinematic link between the Mid-Hungarian fault zone, the Bogdan-Voda fault and the Bogdan-Dragos-Voda fault system since postBurdigalian times. However, since the Bogdan-Voda and Dragos-Voda faults are located within the $\mathrm{Bu}$ covinian basement (i.e. within the Dacia Block) they should not be considered as representing the continuation of the Mid-Hungarian line as defined by Csontos and Nagymarosy (1998). Moreover, the amount of displacement documented for the BogdanDragos-Voda fault system $(\sim 26 \mathrm{~km})$ rapidly diminishes towards the east. Its termination before reaching the foreland fold-and-thrust-belt, as well as the coeval activity at the Preluca fault and faulting south of the Rodna horst, suggests a rather distributed linkage of the foreland fold-and-thrust-belt with the extensional back-arc domain in post-Burdigalian times. This is in agreement with the interpretation of Matenco and Bertotti (2000), who demonstrated that deformation caused by the final ESE-ward emplacement (Latest Sarmatian-Early Meotian, $\sim 10$ to $8 \mathrm{Ma}$ ) was distributed over large parts of the East Carpathians. According to these authors the ESE movement of the central sectors of the Eastern Carpathians was accommodated by numerous E-W trending sinistral faults located east of our study area, rather than by one major strike-slip fault such as the Bogdan-Dragos-Voda fault system.

\section{Conclusions}

1. Early Burdigalian (20.5 to $\sim 18.5 \mathrm{Ma}$ ) SE-directed emplacement of the Pienides, i.e. the eastern tip of ALCAPA, onto Tisza-Dacia is correlated with the thrusting of ALCAPA over Tisza-Dacia along the Mid-Hungarian line observed in the subsurface of the Pannonian basin (Csontos and Nagymarosy 1998). The Pienide nappe front in Maramures is kinematically linked to dextrally transpressive movements along the Mid-Hungarian fault zone that, together with the Periadriatic line, accommodates the lateral extrusion of ALCAPA.

2. Minor Late Burdigalian (18.5 to $16 \mathrm{Ma}$ ) NE-SW extension is interpreted as due to back-arc extension related to subduction roll back in the northernmost East Carpathians.

3. In post-Burdigalian (post-16 Ma) times a pronounced change in the tectonic regime led to NESW shortening and NW-SE extension. This change correlates with "soft collision" of TiszaDacia with the European foreland and the migration of active subduction from $\mathrm{N}$ to $\mathrm{S}$ along the Miocene foredeep of the Eastern Carpathians. Post-Burdigalian deformation was concentrated along the Bogdan-Voda and Dragos-Voda faults. Sinistral transpression (16 to $12 \mathrm{Ma}$ ) was mainly restricted to the Bogdan-Voda fault, which terminated eastwards in a thrust splay geometry. Sinistral transtension (12 to $10 \mathrm{Ma}$ ) was kinematically linked along the Bogdan- and DragosVoda fault segments (Bogdan-Dragos-Voda fault system). During this transtensional stage, coevally active SW-NE trending normal faults reduced the left-lateral offset towards the east, where the fault system terminates in an extensional horse-tail splay. The Bogdan-Dragos-Voda fault system is kinematically linked to the Mid-Hungarian fault zone during the post-Burdigalian stages, albeit deformation is distributed over large parts of the East Carpathians.

Acknowledgments We are very grateful for an excellent introduction into the geology of the area by M. Săndulescu and L. Matenco and for all the discussions we had with them and with all the other Romanian colleagues. We would also like to particularly mention the fruitful interactions with L. Csontos, L. Fodor, S. Kovács, M. Marin, E. Márton, C. Pero, D. Radu, D. Badescu and C. Krezsek during our study. M. Marin is gratefully acknowledged for providing additional data from the eastern part of the study area. The careful and constructive review by L. Ratschbacher significantly improved a first version of the text. This work was financed by NF-projects Nr. 21-64979.01, Nr. 200020-105136/1 and Nr. 200021-101882/1, granted to B.F. and S.Sch., respectively.

\section{Appendix 1}

Table 1. 
Table 1 Tabular overview on fault-slip data

\begin{tabular}{|c|c|c|c|c|c|c|c|c|c|c|c|c|c|}
\hline \multirow{2}{*}{$\begin{array}{l}\text { No. } \\
\text { Data }\end{array}$} & \multirow[t]{2}{*}{$X$} & \multirow[t]{2}{*}{$Y$} & \multirow[t]{2}{*}{ Lithology } & \multirow[t]{2}{*}{ Rock age } & \multicolumn{2}{|c|}{ Shortening } & \multicolumn{2}{|c|}{$\begin{array}{l}\text { Inter-medi- } \\
\text { ate }\end{array}$} & \multicolumn{2}{|c|}{ Extension } & \multirow[t]{2}{*}{$\mathrm{r}$} & \multirow[t]{2}{*}{ Regime } & \multirow[t]{2}{*}{$\begin{array}{l}\mathrm{n} \\
\text { data }\end{array}$} \\
\hline & & & & & & & & & & & & & \\
\hline 0006 & 24.7279 & 47.6816 & Fine flysch & Eocene & 101 & 01 & 206 & 57 & 005 & 31 & 1 & $\begin{array}{l}\text { Compressional } \\
\text { strike slip }\end{array}$ & 36 \\
\hline 0215 & 24.3295 & 47.7339 & Flysch & Oligocene & 324 & 03 & 233 & 22 & 062 & 68 & 3 & Reverse faulting & 3 \\
\hline 0236 & 24.0302 & 47.5991 & Flysch & Eocene & 149 & 21 & 054 & 07 & 308 & 66 & 1 & Reverse faulting & 10 \\
\hline 0248 & 24.0344 & 47.5970 & Red marl & Late Cretaceous & 145 & 12 & 053 & 08 & 290 & 75 & 2 & Reverse faulting & 6 \\
\hline 0272 & 24.1638 & 47.9015 & Conglomerate & L. Alb-Cenomanian & 307 & 14 & 040 & 10 & 164 & 73 & 2 & Reverse faulting & 5 \\
\hline 0288 & 24.4847 & 47.6128 & Flysh & Rupelian & 140 & 03 & 050 & 01 & 306 & 87 & 2 & Reverse faulting & 8 \\
\hline 0291 & 24.4334 & 47.5459 & Red marl & Late Cretaceous & 124 & 02 & 034 & 21 & 219 & 69 & 2 & Reverse faulting & 5 \\
\hline 0314 & 24.2191 & 47.7545 & Flysch & Lutetian-Priabonian & 145 & 00 & 236 & 81 & 055 & 09 & 3 & $\begin{array}{l}\text { Compressional } \\
\text { strike slip }\end{array}$ & 7 \\
\hline 0322 & 24.4250 & 47.5912 & Flysch & Rupelian & 129 & 02 & 219 & 15 & 031 & 75 & 1 & Reverse faulting & 6 \\
\hline 0326 & 24.3450 & 47.4183 & Sandstone & Oligocene & 342 & 16 & 072 & 01 & 167 & 74 & 2 & Reverse faulting & 7 \\
\hline 0414 & 24.3011 & 47.7350 & Flysch & Rupelian & 093 & 04 & 185 & 32 & 357 & 58 & 1 & Reverse faulting & 6 \\
\hline 0453 & 24.4006 & 47.7251 & Flysch & Rupelian & 315 & 02 & 224 & 28 & 049 & 62 & 1 & Reverse faulting & 7 \\
\hline 0584 & 24.0641 & 47.5791 & Flysch & $\begin{array}{l}\text { Priabonian? } \\
\text { Oligocene }\end{array}$ & 158 & 01 & 068 & 07 & 257 & 83 & 1 & Reverse faulting & 18 \\
\hline 0639 & 24.0950 & 47.8813 & Red marl & Late Cretaceous & 137 & 09 & 233 & 36 & 035 & 52 & 1 & $\begin{array}{l}\text { Compressional } \\
\text { strike slip }\end{array}$ & 30 \\
\hline 0692 & 24.0752 & 47.8488 & Flysch & Lutetian-Priabonian & 111 & 18 & 014 & 22 & 237 & 61 & 3 & Reverse faulting & 6 \\
\hline 0743 & 24.7105 & 47.6698 & Marl & Eocene & 102 & 12 & 354 & 54 & 200 & 33 & 3 & Reverse faulting & 5 \\
\hline 0822 & 24.3608 & 47.4721 & Flysch & Rupelian -Aquitanian & 352 & 05 & 261 & 14 & 100 & 76 & 2 & Reverse faulting & 19 \\
\hline 0892 & 24.4782 & 47.5418 & Marl & Turonian-Priabonian & 162 & 23 & 331 & 67 & 070 & 04 & 1 & $\begin{array}{l}\text { Compressional } \\
\text { strike slip }\end{array}$ & 11 \\
\hline 1025 & 24.4616 & 47.5955 & Marl & Turonian-Priabonian & 341 & 05 & 248 & 28 & 079 & 61 & 1 & Reverse faulting & 14 \\
\hline 1056 & 24.1420 & 47.5801 & Flysch & $\begin{array}{r}\text { Priabonian-? } \\
\text { Oligocene }\end{array}$ & 157 & 30 & 037 & 40 & 271 & 35 & 2 & $\begin{array}{l}\text { Compressional } \\
\text { strike slip }\end{array}$ & 5 \\
\hline \multicolumn{14}{|c|}{ Data correlated to Late Burdigalian SW-NE extension } \\
\hline 0236 & 24.0302 & 47.5991 & Flysch & Eocene & 148 & 36 & 306 & 51 & 050 & 11 & 1 & $\begin{array}{r}\text { Extensional } \\
\text { strike slip }\end{array}$ & 29 \\
\hline 0267 & 23.9266 & 47.4746 & Flysch & Chattian-Aquitanian & 251 & 72 & 145 & 05 & 054 & 17 & 3 & Normal faulting & 3 \\
\hline 0368 & 24.9089 & 47.5638 & Crystalline & Basement & 285 & 73 & 114 & 17 & 023 & 03 & 1 & Normal faulting & 14 \\
\hline 0374 & 24.6976 & 47.6213 & Crystalline & Basement & 141 & 12 & 329 & 77 & 232 & 02 & 2 & $\begin{array}{r}\text { Extensional } \\
\text { strike slip }\end{array}$ & 5 \\
\hline 0376 & 24.8780 & 47.5983 & Crystalline & Basement & 184 & 58 & 326 & 26 & 064 & 17 & 1 & $\begin{array}{r}\text { Extensional } \\
\text { strike slip }\end{array}$ & 11 \\
\hline 0633 & 24.3596 & 47.7297 & Flysch & Rupelian & 114 & 61 & 343 & 20 & 246 & 20 & 2 & Normal faulting & 8 \\
\hline 0765 & 25.1171 & 47.5908 & Crystalline & Basement & 144 & 78 & 293 & 10 & 024 & 06 & 3 & Normal faulting & 5 \\
\hline 0792 & 24.7005 & 47.4143 & Crystalline & Basement & 325 & 62 & 109 & 24 & 206 & 15 & 3 & Normal faulting & 3 \\
\hline 0799 & 24.8962 & 47.4492 & Crystalline & Basement & 037 & 68 & 130 & 01 & 221 & 21 & 1 & Normal faulting & 25 \\
\hline 0801 & 24.8055 & 47.4421 & Crystalline & Basement & 357 & 56 & 113 & 17 & 212 & 29 & 2 & Normal faulting & 9 \\
\hline 0802 & 24.5876 & 47.5191 & Crystalline & Basement & 087 & 71 & 297 & 17 & 204 & 09 & 1 & Normal faulting & 43 \\
\hline 0804 & 24.5811 & 47.5256 & Crystalline & Basement & 100 & 69 & 315 & 17 & 222 & 11 & 1 & Normal faulting & 7 \\
\hline 0816 & 24.6441 & 47.3919 & Conglomerate & Eocene & 139 & 36 & 003 & 45 & 248 & 24 & 2 & $\begin{array}{r}\text { Extensional } \\
\text { strike slip }\end{array}$ & 6 \\
\hline 0915 & 24.0888 & 47.6218 & Flysch & Ypresian-Lutetian & 128 & 81 & 331 & 08 & 241 & 03 & 3 & Normal faulting & 3 \\
\hline 0925 & 23.9891 & 47.6164 & Flysch & Ypresian-Lutetian & 161 & 70 & 275 & 08 & 007 & 18 & 2 & Normal faulting & 6 \\
\hline M 30 & 25.1658 & 47.5551 & Crystalline & Basement & 263 & 34 & 116 & 51 & 004 & 16 & 2 & $\begin{array}{r}\text { Extensional } \\
\text { strike slip }\end{array}$ & 11 \\
\hline M 41 & 25.4644 & 47.5276 & Crystalline & Basement & 139 & 12 & 270 & 72 & 046 & 13 & 2 & Strike slip & 8 \\
\hline M 66 & 25.3566 & 47.5826 & Crystalline & Basement & 146 & 19 & 016 & 63 & 243 & 19 & 2 & $\begin{array}{r}\text { Extensional } \\
\text { strike slip }\end{array}$ & 7 \\
\hline \multicolumn{14}{|c|}{ Data correlated to post-Burdigalian transpressional stage } \\
\hline 0008 & 24.2418 & 47.6984 & Tuff & Badenianmj & 050 & 10 & 298 & 65 & 145 & 22 & 1 & $\begin{array}{l}\text { Compressional } \\
\text { strike slip }\end{array}$ & 13 \\
\hline 0059 & 24.8196 & 47.6257 & Conglomerate & Lutetian & 225 & 12 & 130 & 23 & 339 & 63 & 2 & $\begin{array}{l}\text { Compressional } \\
\text { strike slip }\end{array}$ & 9 \\
\hline 0147 & 24.2452 & 47.8174 & Flysch & Lutetian-Priabonian & 024 & 05 & 284 & 66 & 116 & 23 & 2 & $\begin{array}{l}\text { Compressional } \\
\text { strike slip }\end{array}$ & 16 \\
\hline 0237 & 24.0220 & 47.5875 & Flysch & $\begin{array}{l}\text { Oligocene-E. } \\
\text { Miocene }\end{array}$ & 001 & 06 & 298 & 73 & 098 & 16 & 2 & $\begin{array}{l}\text { Compressional } \\
\text { strike slip }\end{array}$ & 11 \\
\hline
\end{tabular}


Table 1 continued

\begin{tabular}{|c|c|c|c|c|c|c|c|c|c|c|c|c|c|}
\hline \multirow{2}{*}{$\begin{array}{l}\text { No. } \\
0259\end{array}$} & \multirow{2}{*}{$\begin{array}{l}X \\
23.6433\end{array}$} & \multirow{2}{*}{$\begin{array}{l}Y \\
47.5093\end{array}$} & \multirow{2}{*}{$\begin{array}{l}\text { Lithology } \\
\text { Crystalline }\end{array}$} & \multirow{2}{*}{$\begin{array}{l}\text { Rock age } \\
\text { Basement }\end{array}$} & \multicolumn{2}{|c|}{ Shortening } & \multicolumn{2}{|c|}{$\begin{array}{l}\text { Inter- } \\
\text { mediate }\end{array}$} & \multicolumn{2}{|c|}{ Extension } & \multirow{2}{*}{$\begin{array}{r}\mathrm{r} \\
1\end{array}$} & \multirow{2}{*}{$\begin{array}{l}\text { Regime } \\
\text { Reverse faulting }\end{array}$} & \multirow{2}{*}{$\begin{array}{l}\mathrm{n} \\
\text { data } \\
7\end{array}$} \\
\hline & & & & & 089 & 01 & 139 & 24 & 317 & 66 & & & \\
\hline 0260 & 23.8639 & 47.4366 & Flysch & Burdigalian & 249 & 06 & 157 & 13 & 006 & 76 & 3 & Reverse faulting & 3 \\
\hline 0276 & 24.2015 & 47.8582 & Flysch & Oligocene & 192 & 16 & 101 & 02 & 004 & 74 & 2 & Reverse faulting & 6 \\
\hline 0310 & 24.1013 & 47.7794 & Flysch & Priabon & 212 & 13 & 321 & 55 & 114 & 32 & 1 & $\begin{array}{l}\text { Compressional } \\
\text { strike slip }\end{array}$ & 12 \\
\hline 0322 & 24.4274 & 47.5643 & Flysch & Rupelian & 037 & 10 & 305 & 11 & 167 & 76 & 3 & Reverse faulting & 2 \\
\hline 0357 & 24.8414 & 47.6499 & Crystalline & Basement & 049 & 03 & 318 & 18 & 147 & 72 & 1 & Reverse faulting & 6 \\
\hline 0360 & 24.9921 & 47.5859 & Flysch & Lutetian & 189 & 04 & 094 & 52 & 282 & 38 & 1 & $\begin{array}{l}\text { Compressional } \\
\text { strike slip }\end{array}$ & 13 \\
\hline 0462 & 24.4936 & 47.6215 & Limestone & Lutetian-Priabonian & 048 & 05 & 313 & 45 & 143 & 45 & 1 & $\begin{array}{l}\text { Compressional } \\
\text { strike slip }\end{array}$ & 6 \\
\hline 0556 & 23.8153 & 47.4966 & Crystalline & Basement & 014 & 08 & 112 & 45 & 276 & 44 & 2 & $\begin{array}{l}\text { Compressional } \\
\text { strike slip }\end{array}$ & 9 \\
\hline 0631 & 24.3719 & 47.8333 & Flysch & Oligocene & 255 & 00 & 345 & 61 & 165 & 29 & 1 & $\begin{array}{l}\text { Compressional } \\
\text { strike slip }\end{array}$ & 5 \\
\hline 0632 & 24.3395 & 47.8286 & Flysch & Oligocene & 054 & 02 & 323 & 25 & 149 & 65 & 2 & $\begin{array}{l}\text { Compressional } \\
\text { strike slip }\end{array}$ & 7 \\
\hline 0675 & 24.2141 & 47.6546 & Flysch & Oligocene & 249 & 03 & 351 & 76 & 159 & 13 & 1 & $\begin{array}{l}\text { Compressional } \\
\text { strike slip }\end{array}$ & 8 \\
\hline 0682 & 24.2234 & 47.6636 & Flysch & Oligocene & 063 & 11 & 159 & 29 & 314 & 59 & 3 & $\begin{array}{l}\text { Compressional } \\
\text { strike slip }\end{array}$ & 5 \\
\hline 0809 & 24.8339 & 47.6486 & Marl/limestone & Lutetian-Priabonian & 210 & 04 & 119 & 02 & 001 & 86 & 1 & Reverse faulting & 12 \\
\hline 0917 & 24.0219 & 47.6177 & Flysch & Ypresian-Lutetian & 245 & 03 & 154 & 17 & 344 & 73 & 2 & Reverse faulting & 13 \\
\hline \multicolumn{14}{|c|}{ Data correlated to post-Burdigalian transtenional stage } \\
\hline 0059 & 24.8196 & 47.6257 & Conglomerate & Lutetian & 144 & 72 & 245 & 03 & 336 & 17 & 1 & $\begin{array}{l}\text { Extensional } \\
\text { strike slip }\end{array}$ & 9 \\
\hline 0060 & 24.7894 & 47.6107 & Crystalline & Basement & 235 & 38 & 063 & 52 & 328 & 04 & 1 & $\begin{array}{r}\text { Extensional } \\
\text { strike slip }\end{array}$ & 11 \\
\hline 0079 & 24.4717 & 47.6215 & Limestone & Lutetian-Priabonian & 223 & 46 & 069 & 41 & 327 & 13 & 1 & $\begin{array}{r}\text { Extensional } \\
\text { strike slip }\end{array}$ & 9 \\
\hline 0095 & 24.4103 & 47.6212 & Flysch & Lutetian-Priabonian & 208 & 76 & 066 & 11 & 334 & 08 & 3 & Normal faulting & 5 \\
\hline 0152 & 24.1337 & 47.6965 & Tuff & Badenian & 219 & 27 & 036 & 63 & 128 & 01 & 2 & $\begin{array}{r}\text { Extensional } \\
\text { strike slip }\end{array}$ & 5 \\
\hline 0170 & 24.1472 & 47.6656 & Flysch & Ypresian-Lutetian & 037 & 16 & 189 & 72 & 304 & 08 & 2 & Strike slip & 5 \\
\hline 0180 & 24.3487 & 47.6356 & Flysch & Lutetian-Priabonian & 245 & 35 & 058 & 55 & 152 & 03 & 2 & $\begin{array}{l}\text { Extensional } \\
\text { strike slip }\end{array}$ & 11 \\
\hline 0236 & 24.0302 & 47.5991 & Flysch/marl & Late Jur-Eocene & 186 & 11 & 072 & 65 & 281 & 22 & 1 & Strike slip & 19 \\
\hline 0259 & 23.6433 & 47.5093 & Crystalline & Basement & 016 & 44 & 193 & 46 & 285 & 02 & 1 & $\begin{array}{r}\text { Extensional } \\
\text { strike slip }\end{array}$ & 7 \\
\hline 0272 & 24.1638 & 47.9015 & Conglomerate & L. Albian-Cenomanian & 077 & 09 & 324 & 67 & 171 & 21 & 2 & Strike slip & 5 \\
\hline 0275 & 24.1536 & 47.8973 & Limestone & Lutetian-Priabonian & 156 & 71 & 038 & 09 & 305 & 16 & 2 & Normal faulting & 7 \\
\hline 0292 & 24.4926 & 47.7065 & Flysch & Rupelian & 069 & 53 & 229 & 35 & 326 & 10 & 2 & $\begin{array}{r}\text { Extensional } \\
\text { strike slip }\end{array}$ & 7 \\
\hline 0297 & 24.5695 & 47.7276 & Flysch & Oligocene & 196 & 24 & 359 & 65 & 103 & 06 & 2 & $\begin{array}{r}\text { Extensional } \\
\text { strike slip }\end{array}$ & 7 \\
\hline 0346 & 25.1493 & 47.5659 & Crystalline & Basement & 316 & 61 & 225 & 00 & 135 & 29 & 2 & Normal faulting & 6 \\
\hline 0360 & 24.9921 & 47.5859 & Sandstone & Lutetian & 203 & 10 & 060 & 77 & 295 & 08 & 1 & Strike slip & 18 \\
\hline 0363 & 24.8924 & 47.6024 & Crystalline & Basement & 213 & 20 & 021 & 70 & 122 & 04 & 1 & Strike slip & 14 \\
\hline 0368 & 24.9089 & 47.5638 & Crystalline & Basement & 273 & 60 & 043 & 21 & 142 & 21 & 2 & Normal faulting & 10 \\
\hline 0369 & 24.6908 & 47.5981 & Crystalline & Basement & 131 & 68 & 023 & 07 & 291 & 21 & 2 & $\begin{array}{l}\text { Extensional } \\
\text { strike slip }\end{array}$ & 11 \\
\hline 0374 & 24.6976 & 47.6213 & Crystalline & Basement & 219 & 14 & 049 & 75 & 310 & 02 & 2 & Strike slip & 20 \\
\hline 0385 & 24.6186 & 47.7480 & Flysch & Oligocene & 227 & 21 & 055 & 68 & 318 & 03 & 2 & $\begin{array}{l}\text { Extensional } \\
\text { strike slip }\end{array}$ & 4 \\
\hline 0386 & 24.6177 & 47.7499 & Crystalline & Basement & 248 & 63 & 080 & 27 & 348 & 05 & 1 & Normal faulting & 12 \\
\hline 0387 & 24.6069 & 47.7611 & Crystalline & Basement & 161 & 70 & 037 & 12 & 303 & 16 & 1 & Normal faulting & 9 \\
\hline 0390 & 24.0066 & 47.8386 & Tuff & Badenian & 016 & 36 & 213 & 53 & 112 & 08 & 2 & $\begin{array}{l}\text { Extensional } \\
\text { strike slip }\end{array}$ & 7 \\
\hline 0413 & 24.8755 & 47.5983 & Crystalline & Basement & 298 & 76 & 178 & 88 & 088 & 12 & 2 & Normal faulting & 8 \\
\hline 0452 & 24.4124 & 47.7375 & Flysch & L. Lutetian/Bartonian & 050 & 73 & 238 & 16 & 147 & 02 & 2 & Normal faulting & 8 \\
\hline
\end{tabular}


Table 1 continued

\begin{tabular}{|c|c|c|c|c|c|c|c|c|c|c|c|c|c|}
\hline \multirow{2}{*}{$\begin{array}{l}\text { No. } \\
0462\end{array}$} & \multirow{2}{*}{$\begin{array}{l}X \\
24.4936\end{array}$} & \multirow{2}{*}{$\begin{array}{l}Y \\
47.6215\end{array}$} & \multirow{2}{*}{$\begin{array}{l}\text { Lithology } \\
\text { Limestone }\end{array}$} & \multirow{2}{*}{$\begin{array}{l}\text { Rock age } \\
\text { Lutetian-Priabonian }\end{array}$} & \multicolumn{2}{|c|}{$\begin{array}{l}\text { Shorten- } \\
\text { ing }\end{array}$} & \multicolumn{2}{|c|}{$\begin{array}{l}\text { Inter- } \\
\text { mediate }\end{array}$} & \multicolumn{2}{|c|}{$\begin{array}{l}\text { Exten- } \\
\text { sion }\end{array}$} & \multirow[t]{2}{*}{$\mathrm{r}$} & \multirow{2}{*}{$\begin{array}{l}\text { Regime } \\
\begin{array}{r}\text { Extensional } \\
\text { strike slip }\end{array}\end{array}$} & \multirow{2}{*}{$\frac{\mathrm{n}}{\mathrm{data}}$} \\
\hline & & & & & 224 & 66 & 051 & 24 & 320 & 03 & & & \\
\hline 0481 & 24.5200 & 47.6219 & Crystalline & Basement & 225 & 51 & 052 & 39 & 319 & 03 & 1 & $\begin{array}{l}\text { Extensional } \\
\text { strike slip }\end{array}$ & 14 \\
\hline 0534 & 23.6282 & 47.5041 & Crystalline & Basement & 022 & 45 & 213 & 44 & 117 & 06 & 3 & $\begin{array}{l}\text { Extensional } \\
\text { strike slip }\end{array}$ & 4 \\
\hline 550 & 23.8101 & 47.4680 & Crystalline & Basement & 320 & 81 & 053 & 00 & 143 & 09 & 3 & Normal faulting & 6 \\
\hline 0556 & 23.8153 & 47.4966 & Crystalline & Basement & 191 & 14 & 055 & 70 & 284 & 13 & 2 & $\begin{array}{l}\text { Extensional } \\
\text { strike slip }\end{array}$ & 9 \\
\hline 0588 & 23.9867 & 47.5482 & Flysch & Early Miocene & 163 & 50 & 032 & 29 & 287 & 25 & 2 & $\begin{array}{l}\text { Extensional } \\
\text { strike slip }\end{array}$ & 11 \\
\hline 0625 & 24.1412 & 47.6479 & Tuff & Ypresian-Lutetian & 244 & 52 & 061 & 38 & 152 & 01 & 1 & $\begin{array}{l}\text { Extensional } \\
\text { strike slip }\end{array}$ & 26 \\
\hline 681 & 24.2230 & 47.6629 & Sandstone & Badenian & 213 & 37 & 051 & 51 & 310 & 09 & 1 & Strike slip & 18 \\
\hline 0712 & 23.9619 & 47.8797 & Sandstone & Badenian & 051 & 64 & 218 & 26 & 311 & 05 & 1 & Normal faulting & 9 \\
\hline 0720 & 24.1340 & 47.6577 & Flysch & Ypresian-Lutetian & 011 & 04 & 116 & 76 & 280 & 14 & 3 & Strike slip & 8 \\
\hline 0733 & 24.0414 & 47.8737 & Tuff & Badenian & 009 & 29 & 202 & 61 & 102 & 05 & 1 & Strike slip & 17 \\
\hline 0758 & 25.1234 & 47.5824 & Dolomite & Basement & 038 & 01 & 132 & 82 & 308 & 08 & 1 & $\begin{array}{l}\text { Extensional } \\
\text { strike slip }\end{array}$ & 23 \\
\hline 0774 & 24.5453 & 47.4003 & Crystalline & Basement & 030 & 39 & 246 & 45 & 136 & 19 & 2 & $\begin{array}{r}\text { Extensional } \\
\text { strike slip }\end{array}$ & 8 \\
\hline 0797 & 24.9295 & 47.4590 & Conglomerate & Cret: & 345 & 46 & 228 & 13 & 133 & 23 & 1 & Normal Faulting & 13 \\
\hline 0799 & 24.8962 & 47.4492 & Crystalline & Basement & 021 & 70 & 198 & 20 & 289 & 01 & 2 & Normal faulting & 9 \\
\hline 0801 & 24.8055 & 47.4421 & Crystalline & Basement & 036 & 61 & 204 & 28 & 296 & 05 & 2 & Normal faulting & 11 \\
\hline 0804 & 24.5811 & 47.5256 & Crystalline & Basement & 035 & 54 & 272 & 21 & 171 & 27 & 2 & $\begin{array}{r}\text { Extensional } \\
\text { strike slip }\end{array}$ & 8 \\
\hline 0807 & 24.5791 & 47.4538 & Crystalline & Basement & 028 & 36 & 219 & 53 & 122 & 05 & 3 & $\begin{array}{r}\text { Extensional } \\
\text { strike slip }\end{array}$ & 4 \\
\hline 0814 & 24.6391 & 47.4729 & Crystalline & Basement & 032 & 04 & 203 & 86 & 302 & 01 & 3 & Strike slip & 10 \\
\hline 0818 & 24.8228 & 47.4932 & Crystalline & Basement & 134 & 82 & 037 & 01 & 307 & 08 & 1 & Normal Faulting & 22 \\
\hline 0832 & 24.2835 & 47.6576 & Flysch & Rupelian & 053 & 08 & 180 & 78 & 321 & 10 & 1 & Strike slip & 21 \\
\hline 0838 & 24.2668 & 47.6507 & Sandstone & Badenian & 022 & 05 & 267 & 78 & 113 & 11 & 1 & Strike slip & 37 \\
\hline 0897 & 23.6856 & 47.5602 & Sandstone & Badenian & 042 & 02 & 148 & 82 & 312 & 08 & 2 & Strike slip & 5 \\
\hline M 19 & 25.0739 & 47.5916 & Crystalline & Basement & 208 & 03 & 101 & 79 & 299 & 10 & 1 & Strike slip & 12 \\
\hline M 27 & 25.1569 & 47.5714 & Crystalline & Basement & 017 & 02 & 162 & 84 & 107 & 05 & 1 & Strike slip & 9 \\
\hline M 32 & 25.1724 & 47.5521 & Crystalline & Basement & 041 & 03 & 139 & 73 & 310 & 17 & 1 & Strike slip & 15 \\
\hline M 41 & 25.4644 & 47.5276 & Crystalline & Basement & 055 & 01 & 150 & 82 & 324 & 08 & 2 & Strike slip & 7 \\
\hline
\end{tabular}

no. reference number of outcrop, prefix M: data provided by Mihai Marin

$X / Y$ coordinates of the outcrops in decimal degrees Lat/Long, WGS 84

shortening/intermediate/extension: orientation of respective mean kinematic axes, derived by eigenvector analysis of the shortening/extensional fields obtained by the right dihedra method (Angelier and Mechler 1977)

$r$ data quality rating: 1 , good; 2 , moderate; 3 , poor

regime tectonic regime of deformation assessed by the distribution of incremental strain axes (Marret and Almendinger 1990). Reverse faulting, normal faulting, strike-slip faulting: well-clustered shortening and extension axes; compressional strike-slip: well clustered shortening axes with great circle distribution of extensional axes; extensional strike-slip: well clustered extension axes with great circle distribution of shortening axes $n$ data number of fault-slip sets attributed to respective regime, only fault-slip sets with certain slip sense have been included 


\section{Appendix 2}

Figure 9.

Legend:

- shortening

$\square$ intermediate

$\triangle$ extension

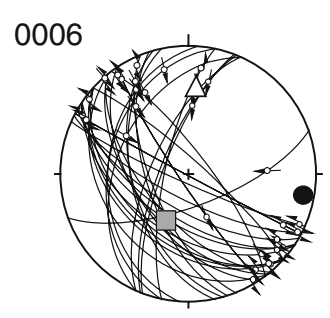

0215

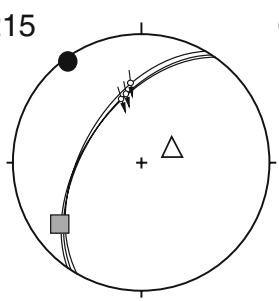

0236

0291

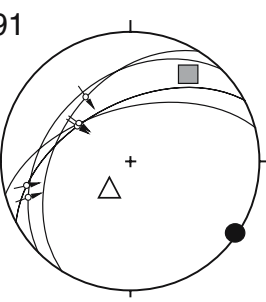

314

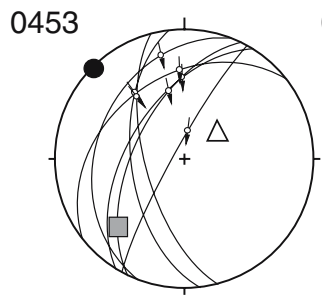

0584

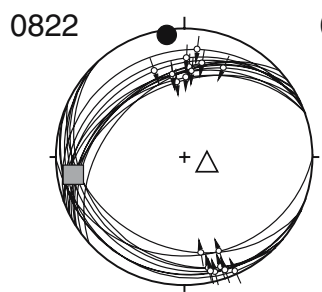

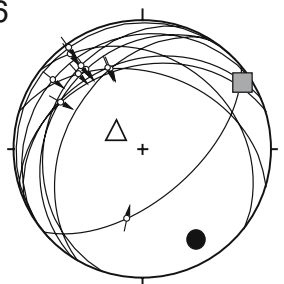
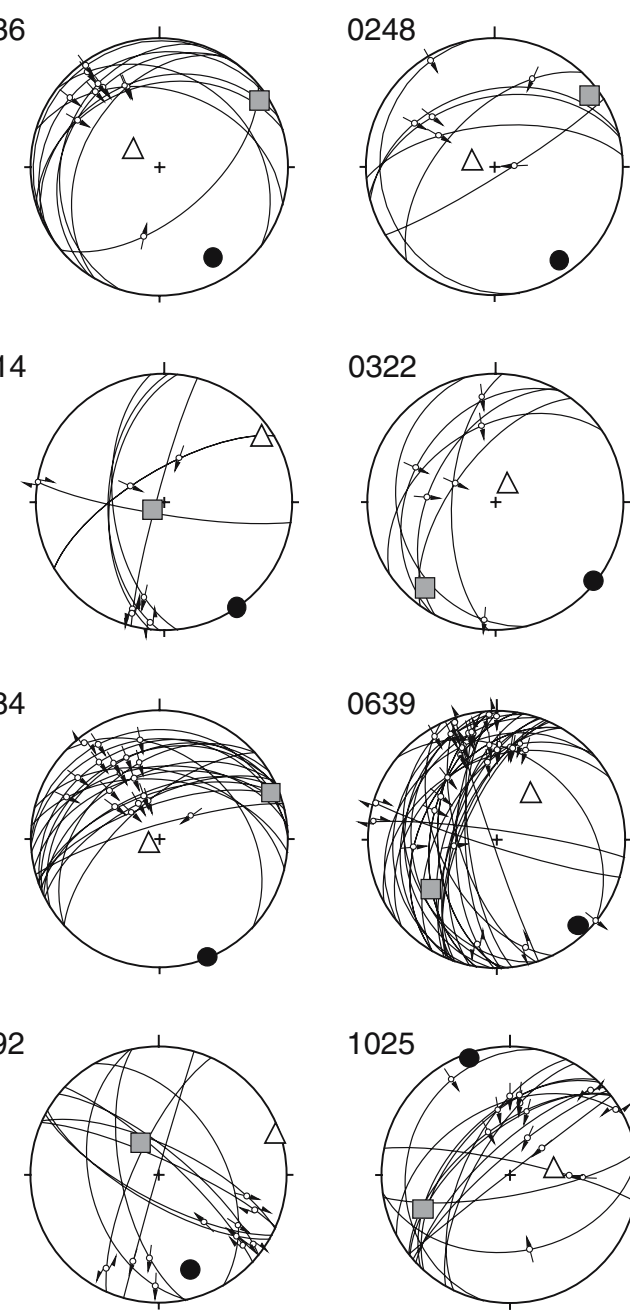

1025

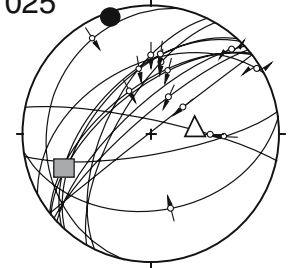

0272

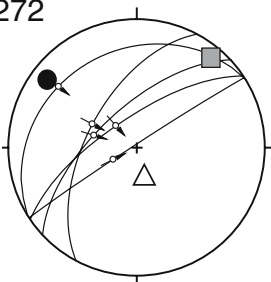

0326

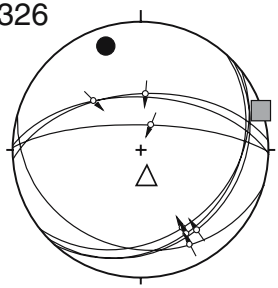

0692

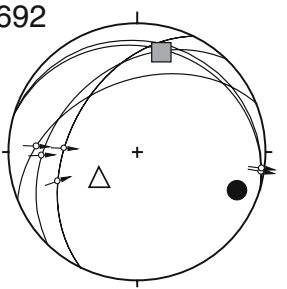

1056

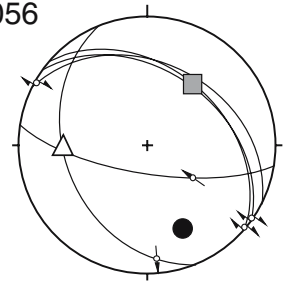

0288

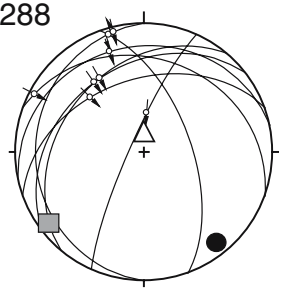

0414
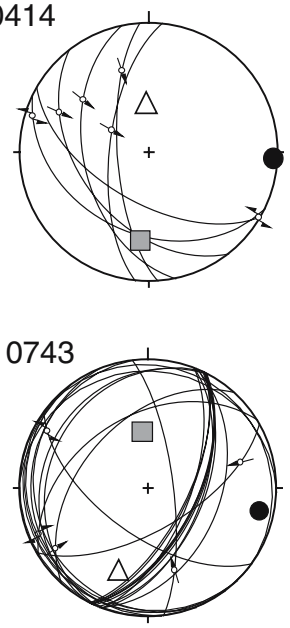

Fig. 9 Fault-slip data (Early Burdigalian top SE-thrusting of the Pienides) 


\section{Appendix 3}

Figure 10.
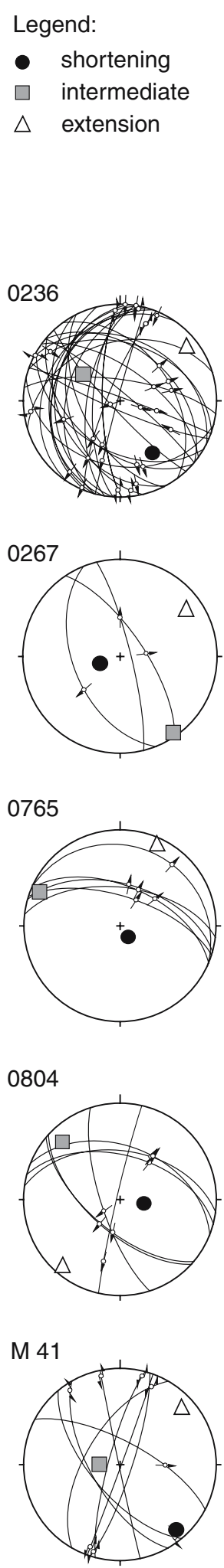
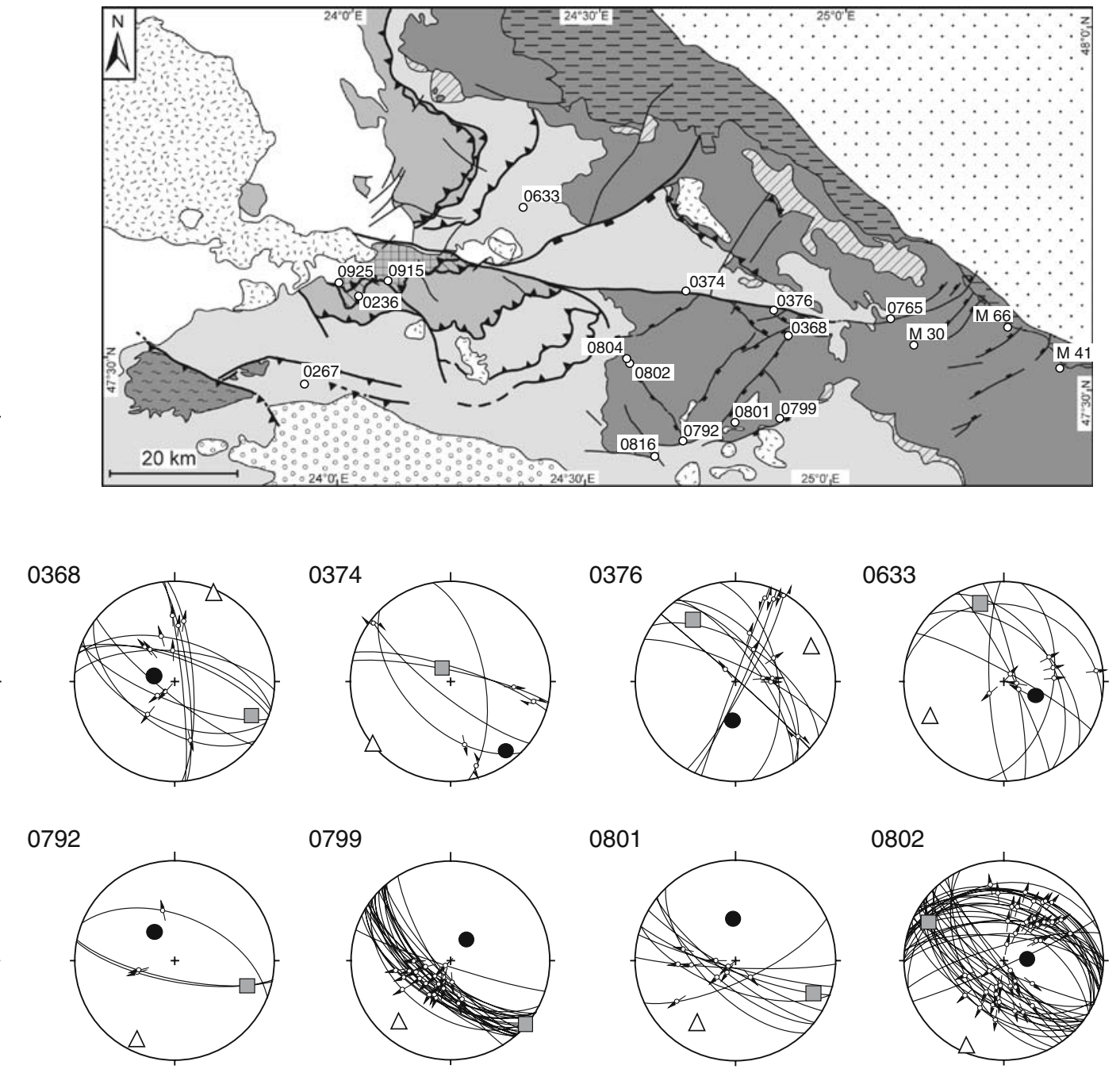

0801
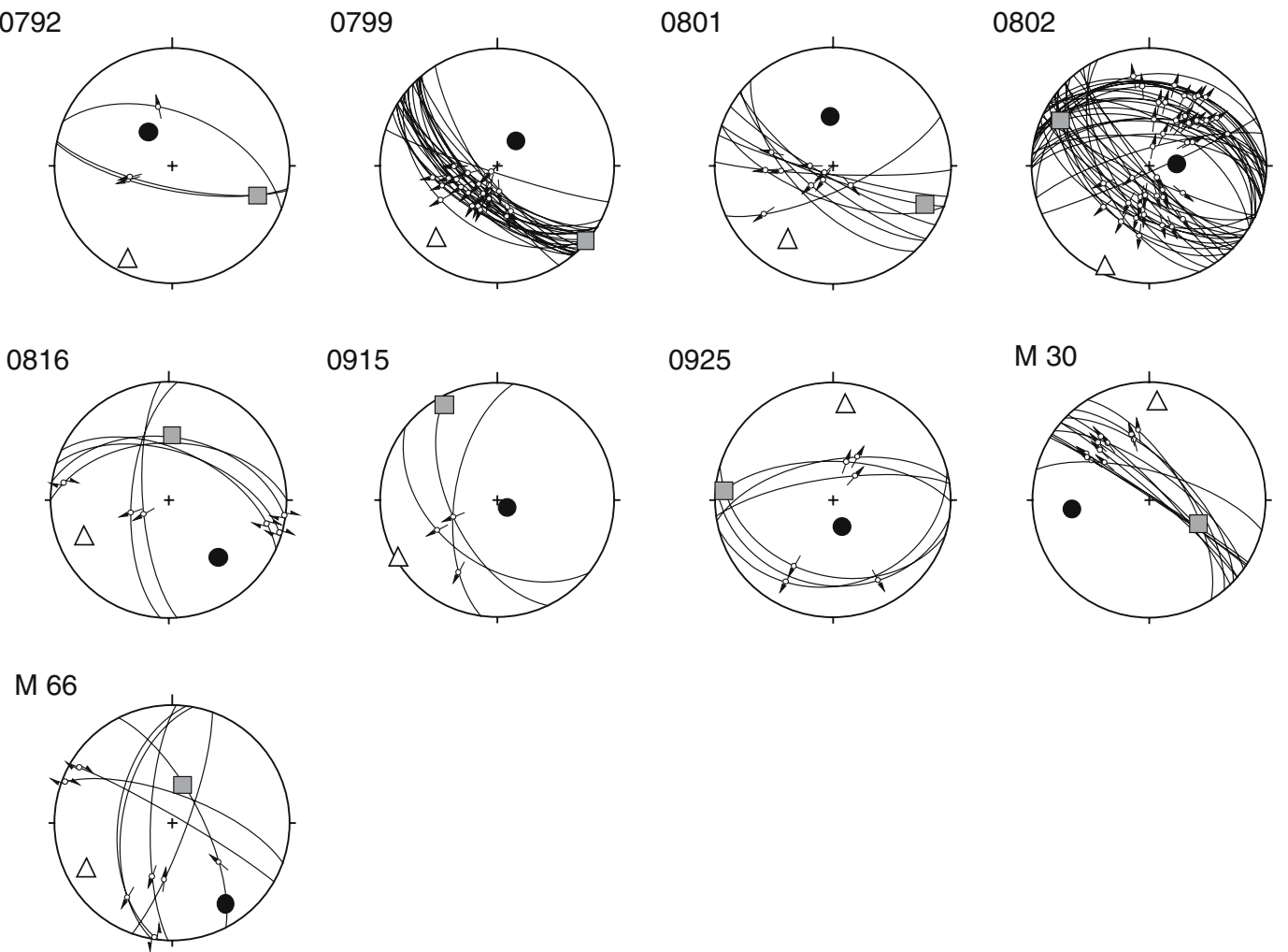

Fig. 10 Fault-slip data (Late Burdigalian NE-SW extension) 


\section{Appendix 4}

Figure 11.

Legend:

- shortening

$\square \quad$ intermediate

$\triangle$ extension
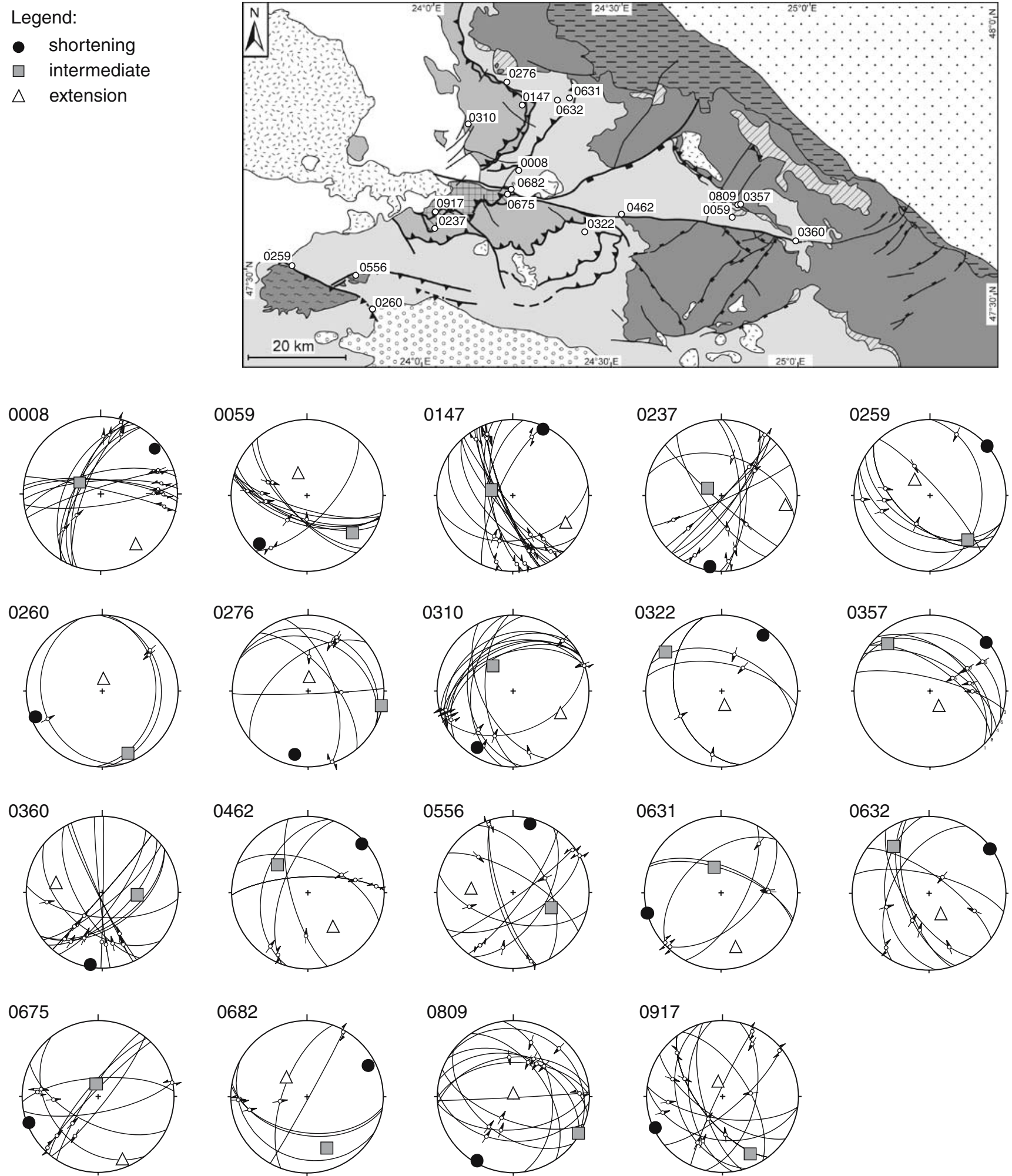

Fig. 11 Fault-slip data (post-Burdigalan transpressional stage) 


\section{Appendix 5}

Figure 12.

Legend:

$\begin{array}{ll}- & \text { shortening } \\ \square & \text { intermediate } \\ \triangle & \text { extension }\end{array}$
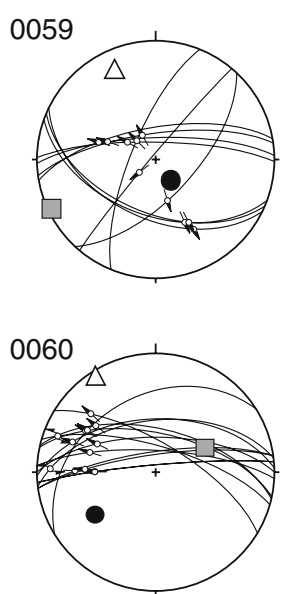

0363

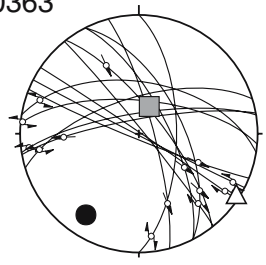

0462
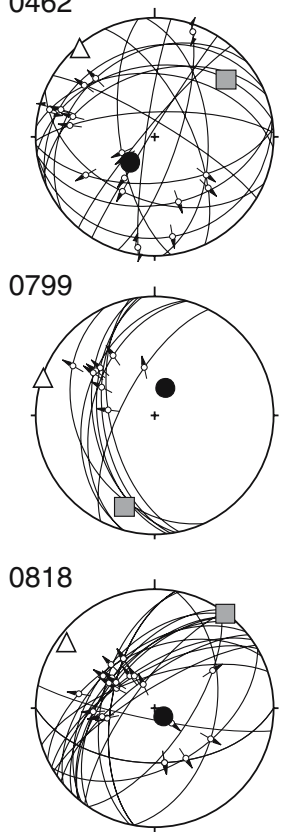

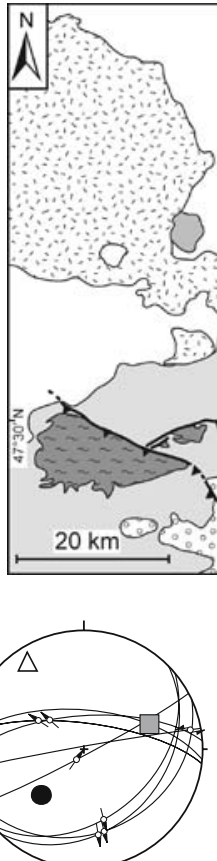

0368

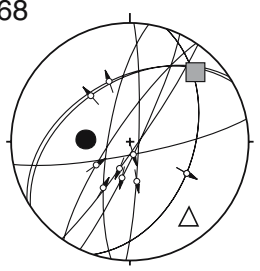

0481

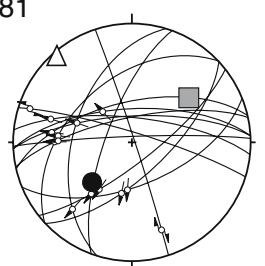

0801

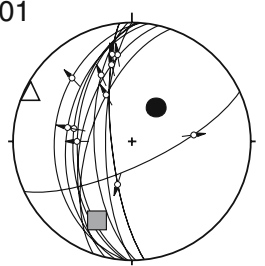

M 19

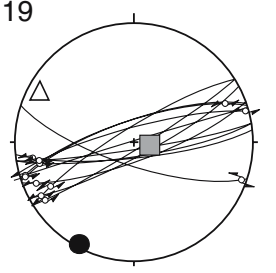

0095

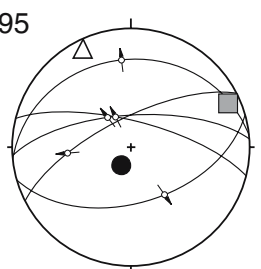

0369

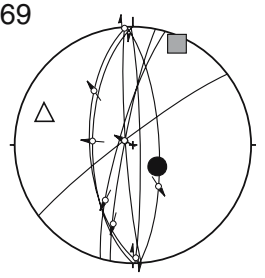

0758

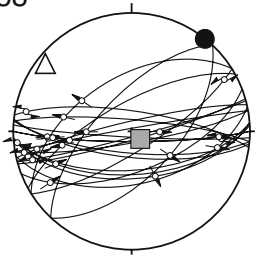

0804

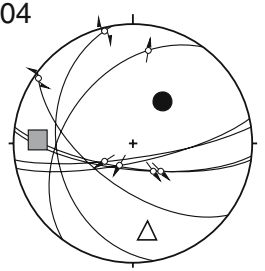

M 27

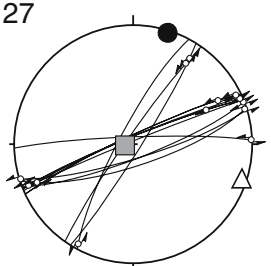

0346

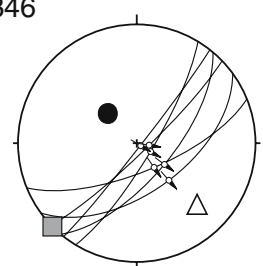

0374

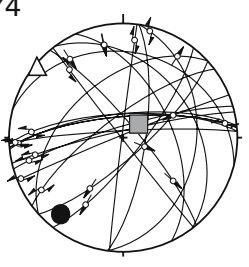

0774

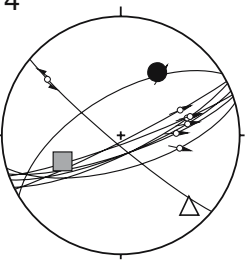

0807

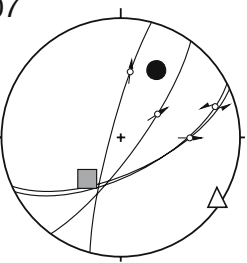

M 32

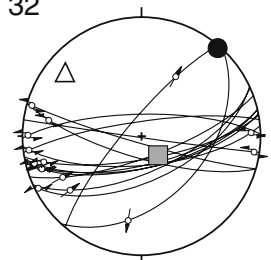

0360

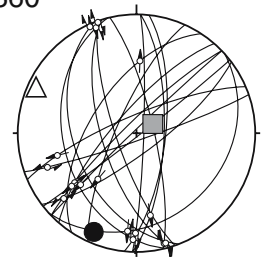

0413

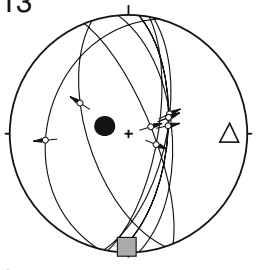

0797

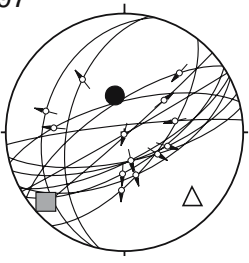

0814

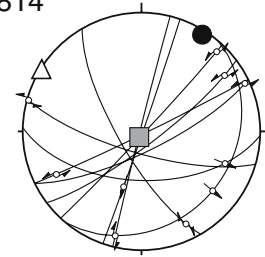

M 64

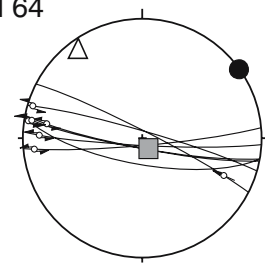

Fig. 12 Fault-slip data (post-Burdigalian transtensional stage, eastern stations) 


\section{Appendix 6}

Figure 13.

Legend:

- shortening

$\square \quad$ intermediate

$\triangle$ extension
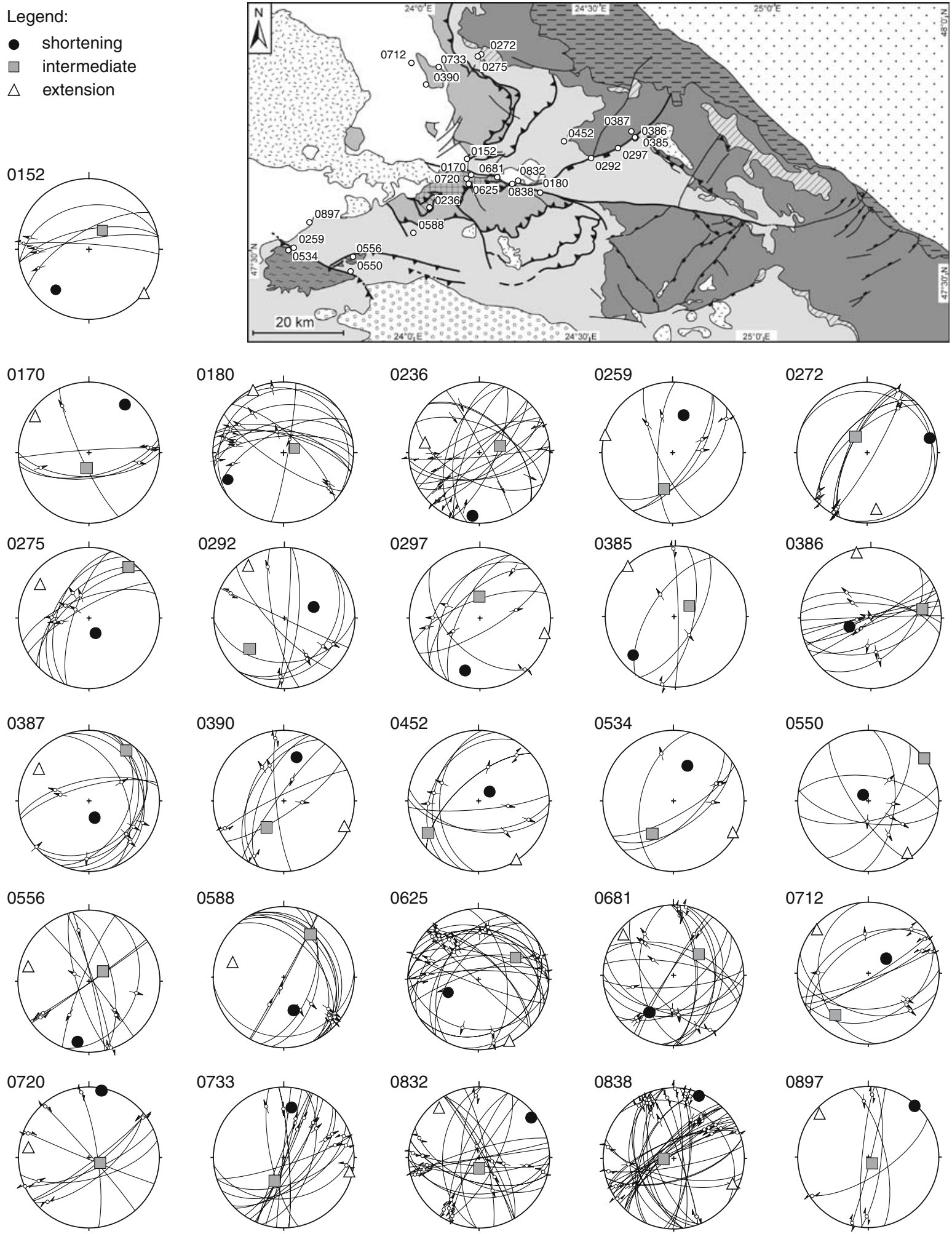

Fig. 13 Fault-slip data (post-Burdigalian transtensional stage, western stations) 


\section{References}

Angelier J, Mechler P (1977) Sur une méthode graphique de recherche des contraintes principales également utilisable en tectonique et enséismologie: la methode des diédres droits. Bull Soc Géol France VII(19):1309-1318

Antonescu F, Mitrea G, Popescu A (1981) Contributii la cunoasterea stratigafiei si tectonicii miocenului din regiunea Vadu Izei-Birsan-Botiza (Maramures). D.S. Inst Geol Geofiz LXVI:5-23

Aroldi C (2001) The Pienides in Maramures-Sedimentation, tectonics and paleogeography. PhD Thesis, Cluj, pp 1-156

Balintoni I (1995) Alpine structural outline of the Pannonian Carpathian realm. Studia Universitates Babes-Bolyai, Geologia XL(2):3-16

Balla Z (1982) Development of the Pannonian Basin basement through the Cretaceous-Cenozoic collision: a new synthesis. Tectonophysics 88:61-102

Balla Z (1987) Tertiary paleomagnetic data for the CarpathoPannonian region in the light of Miocene rotation kinematics. Tectonophysics 139:67-98

Bingham C (1964) Distributions on a sphere and the projective plane. PhD. diss. Yale University, New Haven, pp 1-93

Burchfiel BC (1980) Eastern European Alpine system and the Carpathian orocline as an example of collision tectonics. Tectonophysics 63:31-61

Ciulavu D (1999) Tertiary tectonics of the Transylvanian Basin. PhD diss Vrije Universiteit Amsterdam, Amsterdam, pp 1154

Cloetingh S, Bada G, Matenco L, Lankreijer A, Horváth F, Dinu C (2005) Thermo-mechanical modelling of the PannonianCarpathian system: modes of tectonic deformation, lithospheric strength and vertical motions. Geol Soc London Spec Publ., (in press)

Csontos L, Nagymarosy A (1998) The Mid-Hungarian line: a zone of repeated tectonic inversions. Tectonophysics 297:51-71

Csontos L, Vörös A (2004) Mesozoic plate tectonic reconstruction of the Carpathian region. Paleogeography, Paleoclimatology, Paleoecology 210:1-56

Csontos L, Nagymarosy A, Horváth F, Kováč M (1992) Cenozoic evolution of the Intra-Carpathian area: a model. Tectonophysics 208:221-241

Dicea O, Dutescu P, Antonescu F, Mitrea G, Botez R, Donos I, Lungu V, Morosanu I (1980) Contributii la cunoasterea stratigrafiei zonei transcarpatice din maramures. D. S. Inst Geol Geofiz LXV, 4:21- 85

Dimitrijevic MD (2001) Dinarides and the Vardar Zone: a short review of the geology. Acta Vulcanologica 13:1-8

Dunkl I (2002) Trackkey: a Windows program for calculation and graphical presentation of fission track data. Comput Geosci 28:3-12

Fodor L, Jelen B, Márton M, Skaberne D, Car J, Vrabec M (1998) Miocene-Pliocene tectonic evolution of the Slovenian Periadriatic fault: implications for Alpine-Carpathian extrusion models. Tectonics 17:690-709

Fodor L, Csontos L, Bada G, Györfi I, Benkovics L (1999) Cenozoic tectonic evolution of the Pannonian basin system and neighbouring orogens: a new synthesis of paleostress data. In: Durand B, Jolivet L, Horváth F, Séranne M (eds). The Mediterranean basins: Cenozoic Extension within the Alpine Orogen. Geol Soc Spec Publ 156:295-334

Fügenschuh B, Schmid SM (2005) Age and significance of core complex formation in a highly bent orogen: evidence from fission track studies in the South Carpathians (Romania). Tectonophysics (in press)
Galbraith RF (1981) On statistical models for fission track counts. Math Geol 13:471-488

Galbraith RF, Laslett GM (1993) Statistical models for mixed fission track ages. Nucl Tracks Radiat Meas 21:450-470

Gallagher K, Brown R, Johnson C. (1998) Fission track analysis and its applications to geological problems. Annu Rev Earth Planet Sci 26:519-571

Gleadow AJW (1981) Fission track dating methods: what are the real alternatives? Nucl Tracks 5:3-14

Gleadow AJW, Duddy IR (1981) A natural long-term track annealing experiment for apatite. Nucl Tracks 5(1/2):169 174

Gradstein F, Ogg J, Smith A (2004) A geologic time scale. Cambridge University Press, Cambridge, pp 1-589

Gröger HR (2006) Thermal and structural evolution of the East Carpathians in northern Romania: from Cretaceous orogeny to final exhumation during Miocene collision. Ph.D. thesis, Basel University, Basel, pp 1-111

Györfi I, Csontos L, Nagymarosy A (1999) Early Cenozoic structural evolution of the border zone between the Pannonian and Transylvanian basins. In: Durand B, Jolivet L, Horváth F, Séranne M (eds). The Mediterranean Basins: Cenozoic Extension within the Alpine Orogen. Geol Soc Spec Publ 156:251-267

Haas J, Pero S (2004) Mesozoic evolution of the Tisza Megaunit. Int J Earth Sci 93:297-313

Haas J, Mioč P, Pamić J, Tomljenović B, Árkai P, Bérczi-Makk A, Koroknai B, Kovács S, Rálisch-Felgenhauer E (2000) Complex structural pattern of the Alpine-Dinaridic-Pannonian triple junction. Int J Earth Sci 89:377-389

Horváth F, Bada G, Szafián P, Tari G, Ádám A, Cloetingh S (2005) Formation and deformation of the Pannonian basin: constraints from observational data. Geol Soc London Spec Publ (in press)

Huismanns RS, Bertotti G, Ciulavu D, Sanders CAE, Cloetingh S, Dinu C (1997) Structural evolution of the Transylvanian Basin (Romania): a sedimentary basin in the bend zone of the Carpathians. Tectonophysics 272:249-268

Hurford AJ, Green PF (1983) The zeta age calibration of fission track dating. Isotope Geosci 1:185-317

Kovács S, Haas S, Csazar G, Szederkenyi T, Buda G, Nagymarosy A (2000) Tectonostratigraphic terranes in the preNeogene basement of the Hungarian part of the Pannonian area. Acta Geol Hung 43/3:225-328

Kräutner HG, Krä0utner F, Szasz L (1982) Geological Map 1:50.000 No 20a Pietrosul Rodnei. Institutul de Geologie si Geofizica, Bucharest

Marret R, Allmendinger RW (1990) Kinematic analysis of fault slip-data. J Struct Geol 12:973-986

Márton E, (2000) The Tisza Megatectonic Unit in the light of paleomagnetic data. Acta Geol Hung 43/3:329-343

Márton E, Fodor L (1995) Combination of palaeomagnetic and stress data-a case study from North Hungary. Tectonophysics 242:99-114

Márton E, Fodor L (2003) Tertiary paleomagnetic results and structural analysis from the Transdanubian range (Hungary): rotational disintegration of the ALCAPA unit. Tectonophysics 363:201-224

Mason PRD, Seghedi I, Szákasc A, Downes H (1998) Magmatic constraints on geodynamic models of subduction in the Eastern Carpathians, Romania. Tectonophysics 297:157-176

Matenco L, Bertotti G (2000) Tertiary tectonic evolution of the external East Carpathians (Romania). Tectonophysics 316:255-286 
Matenco L, Bertotti G, Cloetingh S, Dinu C (2003) Subsidence analysis and tectonic evolution of the external CarpathianMoesian Platform during Neogene times. Sediment Geol 156:71-94

Nemčok M (1993) Transition from convergence to escape: field evidence from the West Carpathians. Tectonophysics 217:117-142

Pamic J (2000) Basic geological features of the Dinarides and South Tisia. In: Pancardi 2000 Fieldtrip Guidebook (eds. Pamic, J. and Tomljeenovic, B.). Vijesti 37/2:9-18

Pécskay Z, Edelstein O, Kovacs M, Bernád A, Crihan M (1994) $\mathrm{K} / \mathrm{Ar}$ age determination of Neogene volcanic rocks from the Gutai Mts. Geol Carp 45(6):357-363

Pécskay Z, Edelstein O, Seghedi I, Szakács A, Kovacs M, Crihan M, Bernád A (1995) K-Ar datings of Neogene-Quaternary calc-alkaline volcanic rocks in Romania. In: Downes $\mathrm{H}$, Vaselli $\mathrm{O}$ (eds). Neogene and related magmatism in the Carpatho-Pannonian Region. Acta Vulcanologica 7:53-61

Plasienka D, Grecula P, Mutis M, Kováč M, Hovorca D (1997a) Evolution and structure of the Western Carpathians: an overview. In: Grecula P, et al (eds) Geological Evolution of the Western Carpathians. Mineralia Slovaca Monograph, Bratislava pp 1-24

Plasienka D, Putis M, Kováč M, Sefara J, Hrussecky I (1997b): Zones of Alpidic subduction and crustal underthrusting in the Western Carpathians. In: Grecula P, et al (eds) Geological Evolution of the Western Carpathians. Mineralia Slovaca Monograph, Bratislava, pp 35-42

Pfiffner OA, Burkhard M (1987) Determination of paleo-stress axes orientations from fault, twin and earthquake data. Annales Tectonicae 1(1):48-57

Ratschbacher L, Merle O, Davy P, Cobbold P (1991a) Lateral extrusion in the Eastern Alps; Part 1, boundary conditions and experiments scaled for gravity. Tectonics 10(2):245- 256

Ratschbacher L, Frisch W, Linzer HG, Merle O, (1991b) Lateral extrusion in the Eastern Alps; Part 2, structural analysis. Tectonics 10(2):257- 271

Ratschbacher L, Linzer HG, Moser F, Strusievicz RO, Bedelean H, Har N, Mogos PA (1993) Cretaceous to Miocene thrusting and wrenching along the central South Carpathians due to a corner effect during collision and orocline formation. Tectonics 12(4):855-873

Royden LH (1988) Late Cenozoic Tectonics of the Pannonian Basin System In: Royden LH, Horváth F (eds). The Pannonian Basin; a study in basin evolution. AAPG Mem 45:27-48

Sanders C (1998) Tectonics and erosion: competitive forces in a compressive orogen. A fission track study of the Romanian Carpathians. Ph.D. thesis, Vrije Universiteit Amsterdam, Amsterdam, pp 1-204

Săndulescu M (1980) Sur certain problèmes de la corrélation des Carpathes orientales Roumaines avec les Carpathes Ucrainiennes. D S Inst geol geofiz LXV(5):163-180
Săndulescu M, (1984) Geotectonica Romaniei. Editura Tehnica, Bucharest, pp 1-450

Săndulescu M (1994) Overview of Romanian Geology. In: ALCAPA II field guide book. Romanian J of Tectonics and Reg Geol 75(suppl 2):3-15

Săndulescu M, Kräutner HG, Balintoni I, Russo-Săndulescu D, Micu M (1981) The Structure of the East Carpathians. (Guide Book B1), Carp-Balk Geol Assoc 12th Congress, Bucharest, pp 1-92

Săndulescu M, Szasz L, Balintoni I, Russo-Săndulescu D, Badescu D (1991): Geological Map 1:50.000 No 8d Viseu. Institutul de Geologie si Geofizica, Bucharest

Săndulescu M, Visarion M, Stanica D, Stanica M, Atanasiu L (1993) Deep Structure of the inner Carpathians in the Maramures-Tisa zone (East Carpathians). Rom J Geophys 16:67-76

Schmid SM, Berza T, Diaconescu V, Froitzheim N, Fügenschuh B (1998) Orogen-parallel extension in the South Carpathians. Tectonophysics 297:209-228

Schmid SM, Fügenschuh B, Kissling E; Schuster R (2004a) Tectonic map and overall architecture of the Alpine orogen. Eclogae geologicae Helvetiae 97:93-117

Schmid SM, Fügenschuh B, Kissling E; Schuster R (2004b) TRANSMED Transects IV, V and VI: Three lithospheric transects across the Alps and their forelands. In: Cavazza W, Roure FM, Spakman W, Stampfli GM, Ziegler PA (eds). The TRANSMED Atlas: The Mediterranean Region from Crust to Mantle. Springer, Berlin Heidelberg, attached CD (version of the explanatory text available from the first author as a pdf-file upon request)

Sperner B, CRC 461 Team (2005) Monitoring of Slab Detatchment in the Carpathians. In: Wenzel F (ed). Perspectives in modern Seismology. Lecture Notes in Earth Sciences 105:187-202

Sperner B, Ratschbacher L, Nemčok M (2002) Interplay between subduction retreat and lateral extrusion: tectonics of the Western Carpathians. Tectonics 21(6):1051

Stampfli GM, Borel G (2004) The TRANSMED transects in space and time: constraints on the paleotectonic evolution of the Mediterranean domain. In: Cavazza W, Roure FM, Spakman W, Stampfli GM, Ziegler PA (eds) The TRANSMED Atlas: the Mediterranean Region from Crust to Mantle. Springer, Berlin and Heidelberg, pp 53-80

Steininger FF, Wessely G (2000) From the Thethyan Ocean to the Paratethys Sea: Olicocene-Neogene Stratigraphy, Paleogeography and Paleobiogeography of the circumMediterranean region and the Oligocene-Neogene Basin evolution in Austria. Mitt Österr Geol Ges 92:95-116

Wortel MJR, Spakman W (2000) Subduction and slab detachment in the Mediterreanean-Carpathian region. Science 290:1910-1917 